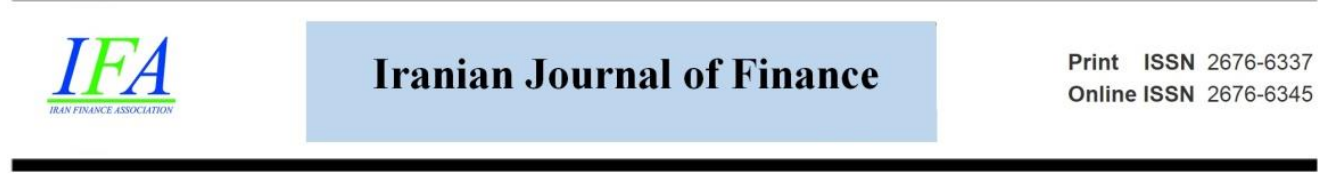

\title{
The model for measuring the Quality of Sustainability Reporting and Determinants: Application Analytic Network Process Fuzzy DEMATEL-Based Technique
}

\section{Habib Esmaeilzadeh}

Ph.D. Candidate, Department of Accounting, Kashan Branch, Islamic Azad University, Kashan, Iran. (Email: esmaeilzadeh.hbib@gmail.com)

\section{Hasan Ghodrati*}

*Corresponding Author, Assistant Prof., Department of Accounting, Kashan Branch, Islamic Azad University, Kashan, Iran. (Email: dr.ghodrati42@gmail.com)

\section{Hossein Jabbari}

Assistant Prof., Department of Accounting, Kashan Branch, Islamic Azad University, Kashan, Iran. (Email: hsnjabbary@yahoo.com)

\section{Meysam Arabzadeh}

Assistant Prof., Department of Accounting, Kashan Branch, Islamic Azad University, Kashan, Iran. (Email: arabzadeh62@yahoo.com)

Document Type: Original Article

Received: 2021/06/17
2022, Vol. 6, No. 2. 28-69.

Published: 2022/02/18

\begin{abstract}
Sustainability reporting is an important tool for decreasing information asymmetry, according to the stakeholders' demands for transparency. On the other hand, increasing transparency allows investors to have more appropriate evaluations of firms' activities and direct their investments to companies with more enthusiasm. In the organizational context, information asymmetry creates conflict between owners and managers. Managers tend to reduce the gap
\end{abstract}


between themselves and stakeholders, particularly shareholders, by producing and delivering reports. Companies use sustainability reports to connect with their society and environment, as well as a way to manage interactions with various stakeholders for societal approval and activity continuation. The primary purpose of this study is to provide a model for measuring the quality of sustainability reporting and the determinants. In terms of methodology, the current study is qualitative, deductive, cross-sectional, applied, and exploratory. The criteria were identified and extracted, then evaluated and prioritized using Multi-Criteria Decision-Making approaches including Fuzzy Analytic Hierarchy Process and Fuzzy Decision-Making Trial and Evaluation Laboratory Analytic Network Process-based. The FAHP test revealed that of the six indicators, the GRI's reporting guidelines for sustainability Checklist were placed highest. Internal Controls Reporting, Sustainability Innovation Performance, and Earnings Quality rated first to third, respectively, among the 25 criteria affecting the quality of sustainability reporting, according to the FDANP.

Keywords: Sustainability Reporting Quality, Internal Controls Reporting, Sustainable Innovation Performance, Earnings Quality, Value Relevance, FDANP

DOI: https://doi.org/ 10.30699/IJF.2021.291022.1246 Publisher: Iran Finance Association

\section{Introduction}

Sustainability reporting has long been recognized as an important tool for organizations and companies to satisfy the rising need for transparency from customers, investors, and other stakeholders (Martinez et al., 2016). Firms, voluntarily report information on their economic, environmental, and social consequences through sustainability reports. This tool enables enterprises to eliminate information gaps and enhance the transparency of their good and bad performance over time (Nobanee and Ellili, 2016). Furthermore, increased transparency helps investors to make more accurate assessments of firms' activities and to better target their investments. Firms that demonstrate social commitment, accountability, and sustainability in their behavior acquire the legitimacy and social acceptability required by the community, and therefore stronger competitive positions and competitive advantages in the market (Martinez et al., 2016). As a result, many companies and organizations are paying more attention to sustainability concerns, as well as the adoption of 
innovative business models and reporting techniques (Clark, Feiner, and Viehs, 2015). In the organizational context, information asymmetry, according to agency theory, creates a gap between shareholders and managers. According to signaling theory, managers strive to reduce the gap between themselves and stakeholders, particularly shareholders, by releasing a sign (report), i.e., relevant information (with information content) and quality, to various parties (Bae et al., 2018). Firms utilize sustainability reports as a tool to interact with the community and the environment, as well as to manage interactions with various stakeholders, to be acceptable in society according to legitimacy and stakeholders' theories (Behbahaninia and Golbidi, 2020).

Considering scientific studies on environmental and societal problems, stakeholders are becoming more aware of the issues and want companies to be held accountable (Yatiridis, 2013; Dissanayanke et al., 2016). In the mid1990s, a global trend began for companies to include social and environmental information in their annual reports. Around 1998, firms began producing their own environmental reports, with 35 percent of American companies doing so. The International Corporate Governance Network (ICGN) reminded the business community that the environment is an important factor to consider when measuring corporate value, current and future opportunities and risks, and investing (El-Rahman, 2019). According to the GRI Database, 4445 entities from all around the globe prepared 4595 sustainability reports using GRI standards in 2020. Table 1 illustrates some of the countries that have reported on sustainability. Iran has four authorized organizations that represent the worldwide movement of companies reporting on sustainability. Ayandeh Bank, Fajr Energy Complex, Mapna, and Nouri Petrochemical Complex are the four Iranian organizations that have developed standard and certified sustainability reports.

Table 1. A number of reporting countries based on the GRI Database in 2020

\begin{tabular}{|l|l|l|l|l|l|l|l|l|}
\hline Nations & USA & Germany & France & UK & Turkey & KSA & UAE & Iran \\
\hline Organization & 367 & 169 & 32 & 64 & 44 & 12 & 35 & 4 \\
\hline Report & 444 & 217 & 38 & 67 & 62 & 16 & 55 & 5 \\
\hline
\end{tabular}

Sustainability reports have made significant progress in various areas over the last few decades, but there are growing concerns about their quality (Michelon, 2015). Academic scholars have been examining the quality of sustainability reporting in different contexts in recent years. For example, Chauvey et al. (2015) reported low sustainability reporting quality in France. According to previous research in the United States, sustainability reporting is 
a critical component (Cho et al., 2012). According to Michelon et al. (2015), the publishing of independent reports provides more information, but the quality is low. In a study conducted in the Netherlands, Gao et al. (2016) reported that firms with higher quality sustainability reporting received economic benefits such as institutional investment, increased coverage by financial analysts, and liquidity through the sale of more stocks. Al-Shaer and Khan (2016) found that the quality of sustainability reporting was positively and substantially linked with the success of gender diversity boards and independent female CEOs in the United Kingdom. Their following research in the United Kingdom (Al-Shaer and zaman, 2018) found that the presence of audit committees had an impact on the quality assurance of sustainability reporting. Other fascinating instances have been investigated in recent studies.

Rezaee and Tao (2019) found that when sustainability reporting quality was high in the United States, the positive correlation between sustainability reporting and the quality of intrinsic earnings was stronger. Diouf and Bioral (2017) conducted a study in Canada on stakeholder views of the impact and distribution of sustainability reporting. In earlier research, the authors conceived and assessed the quality of sustainability reporting. Rezaee and Tao (2019), for example, define sustainability reporting as the quantity of sustainability data and the GRI framework. Other research, such as Al-Shaer and Zaman (2018), used external assurance to determine the quality of sustainability reporting (independent auditing). According to the government's approach, Gao et al. (2016) looked at the quality of sustainability reporting from five perspectives: relevance, clarity, reliability, accountability, and coherence. Other studies have defined sustainability reporting quality in terms of three dimensions: content, validity, and communication (Helfaya et al., 2019) or four dimensions: relative quantity, density, accuracy, and management orientation (Michelon et al., 2015). relevance, comparability, verifiability, clarity, and neutrality are five essential characteristics of sustainability reporting quality information, according to Chauvey et al. (2015). To assess the quality of sustainability reporting, Khan et al. (2020) employed the criteria of relevance (information content) and verifiability.

To ensure the quality of sustainability reporting, the Global Reporting Initiative (GRI) has established principles that focus on it. Stakeholders, including investors, accuracy, balance, clarity, comparability, verifiability, and timeliness, among other aspects. It enables them to analyse the firm's performance correctly and logically and take necessary action. The writers of this paper were encouraged to "Explain the model for measuring the quality of 
sustainability reporting and the determinants" given the fact that there are no studies on the subject in Iran.

In comparison to previous domestic research, the current study stands out by identifying, extracting, refining, and rating the indicators, as well as assessing the quality of sustainability reporting and determinants. The combined approaches of Analytic Network Process (ANP) and DecisionMaking Trial and Evaluation Laboratory (DEMATEL) based on Fuzzy Inference System (FIS) were utilized for the first time in Iran in this study to investigate the internal linkages of factors affecting the model. Given this focus, we expect the current study, as well as the beginnings of quantitative analysis based on the identified factors in the field of reporting quality, to be long-lasting and beneficial to stakeholders, notably investors.

This research helps stakeholders, particularly investors, in evaluating a company's performance using non-financial quality data that includes all economic, social, and environmental dimensions. This information enables them to correctly and effectively estimate their risk and return on investment. On the other hand, it has created a management tool for directors to make appropriate decisions by taking an efficient approach and decreasing debt expenses, business political costs, and enhancing their incentives. What are the model findings for assessing the quality of sustainability reporting and the factors that influence it? is the main question of the study.

The main purpose of this research is to describe the model for determining the quality of sustainability reporting as well as the factors that influence it. Furthermore, the first sub-objective is to develop and extract metrics or models for assessing the quality of sustainability reporting using content analysis of the academic literature. The second sub-objective is to investigate the research literature and use content analysis to find and extract the factors affecting the quality of sustainability reporting. The third sub-objective is to use a Delphi survey and Multi-Criteria Decision-Making models, such as FAHP and FDANP methods, to purify the identified and extracted metrics or patterns of sustainability reporting quality and determinants. Their internal relationships are identified and ranked in the end.

The current study contributes to the existing body of knowledge on sustainability reporting by addressing four major issues. First, the findings of this study may be used to create theoretical basics for literature on corporate sustainability, governance, and financial governance. Second, corporate managers will use the findings of this study to constantly create value by maximizing positive aspects and decreasing negative aspects. Third, advising 
policymakers, such as the auditing organization, the Securities and Exchange Commission to develop reporting standards and regulations. Fourth, the proposed model would provide a new paradigm and scope for academics to use in future research to quantitatively investigate and evaluate the factors influencing the quality of sustainability reporting.

\section{Literature Review}

\section{Sustainability reporting}

The World Commission on Environment and Development established the aspirational aim of sustainable progress in 1987, defining it as "development that fulfills current demands without affecting future generations' ability to satisfy their own needs." As a result, organizations play a critical role in accomplishing this aim. All organizations contribute to sustainable development in good and bad ways through their actions and interactions. Sustainability reporting, as defined by the GRIs, is an organization's method of publicly reporting on its economic, environmental, and social effects, as well as its positive and negative contributions to the goal of sustainable development. Throughout this procedure, a firm determines its significant economic, environmental, and societal consequences and discloses them in accordance with a globally accepted standard. The GRIs provide a common vocabulary for organizations and stakeholders to agree on and understand the economic, environmental, and social effects of organizations. The Standards are intended to increase worldwide comparability and quality of the information on these consequences by allowing for more transparency and accountability. GRIbased sustainability reporting should portray a fair and reasonable picture of an organization's positive and negative contributions to sustainable development. The statement prepared through sustainability reporting allows internal and external stakeholders to form opinions and make enlightened decisions regarding an organization's engagement in sustainable development.

Relevant and key firm stakeholders have reported the influence of the quality of sustainability reports on decision-making in various sustainable development goals throughout the world. Firms that want to maintain their credibility, on the other hand, reveal more consistent, unrealistic, and deceptive information (Chou et al., 2018). Furthermore, when publishing good vs negative sustainability information, stakeholders are only exposed to positive news, which has an impact on their trust in sustainability reports (Unerman et al., 2014). This tarnishes a company's reputation, and such conduct is hazardous to long-term development in terms of the influence of corporate 
performance on society. As a result, the fundamental goal of the sustainability performance report is not met (Unerman et al., 2014). Firms use sustainability performance reports as a linguistic tool to portray a different picture of themselves by releasing reliable data solely to legitimize their performance in such instances (Gary, 2010; Chou et al., 2012; Milne \& Gray, 2013). Stakeholder pressure for a transparent and credible corporate sustainability report to illustrate firm sustainability commitments in a realistic approach grows as a result of this (Al-Shaer \& Zaman, 2016).

\section{Agency Theory}

Despite firms' ongoing efforts to disseminate more additional information about their performance, there is a critical information asymmetry between stakeholders and management, which is a significant activity in the reporting way (Briem and Wald, 2018). Information asymmetry is a situation in which one person has more information than the other. It frequently occurs between management and shareholders. The main objective of reducing information asymmetry between managers and shareholders is to provide a high level of transparency in company performance, allowing shareholders to analyze company conduct in greater depth (Jensen and Berg, 2012). Transparency in corporate reporting refers to the quantity of information about an organization that is available to allow outside groups (such as auditing firms) to monitor internal operations and performance (Hamed et al., 2020). Transparency is a basic and essential component in enhancing public accountability. Agency and legitimacy theories give a comprehensive viewpoint to support the idea that transparency is a fundamental and vital factor in improving public accountability (Stefanescu et al., 2016). Voluntary disclosure is one of the numerous strategies to enhance reporting transparency. Voluntary disclosure helps to alleviate information asymmetry and agency issues by providing relevant information about the firm. Transparency is also a sign of improving operational quality and cost-effectiveness (Sehar and Tufail, 2013).

\section{Stakeholder Theory}

Firms can have a more effective relationship with stakeholders by achieving the stated goals, according to stakeholder theory. This relationship also improves the company's reputation and has a beneficial impact on its financial success (Bose et al., 2017). Responsive to stakeholder requests also contributes to a competitive edge and long-term viability (Needless et al., 2016). This idea also claims that meeting stakeholder expectations and being able to respond to their demands is essential for a company's legitimacy and long-term success (Ferri et al., 2016). In this regard, Oshika and Saka (2017) concluded that the 
major reason for Japanese firms' long-term viability was because management adopted "the idea of stakeholder satisfaction" for economic performance and included it into their sustainability reports. Following the global financial crisis of 2008, stakeholders, regulators, and others focused their attention on a company's long-term viability and sustainability (Adams and Simnett, 2011). As a result, they (stakeholders) want more non-financial data and encourage firms to include more information in their annual reports regarding corporate governance, social and environmental concerns, and sustainability (Comilleri, 2018; Needles et al., 2016; Velte and Stawinoga, 2017).

\section{Legitimacy Theory}

Legitimacy in society is a key strategic component for businesses looking to grow in the future. Legitimacy may be used to develop a business strategy, particularly when it comes to the firm's social standing. Organizations are continuously seeking for strategies to assure their performance within society's scope, context, and standards, according to the legitimacy hypothesis. Legitimacy is a mental state of individuality and a group of persons who are hypersensitive to both physical and non-physical signs of the environment. As a consequence, legitimacy varies according to the location and time coordinates. According to the legitimacy theory, organizations are always on the lookout for ways to ensure that their performance stays within the limits and norms set by society. According to this notion, organizations seek legitimacy by conforming to the standards and guidelines established by the society in which they function (Ruhana and Hidayah, 2020).

\section{Signaling Theory}

In a competitive environment, signaling theory is concerned with resolving information imbalance (Taj, 2016). This theory focuses on management's objective of disseminating market, stakeholder, and community information and signals. In the organizational context, information asymmetry can lead to disputes between owners and agents, but the sign bridges the gap by delivering relevant and high-quality information to all stakeholders. Furthermore, highquality signals (information) suggest that outsiders (buyers, investors) can rapidly grasp the company's capabilities (to bear and manage expenses) and, as a result, the amount to which sales and stock prices may grow. The price of a stock on the market might suddenly rise. As a result, management should consider signaling as a strategic instrument in the decision-making process for social and environmental investments. Furthermore, sign theory explains the trustworthiness of signs as a tool for honesty, as well as management's willingness and commitment to society and stakeholders (Mavlanova et al., 2012). 
Committed management sends out positive signals that improve the dependability of information (Taj, 2016). As a result, companies use numerous techniques to transmit signals to stakeholders to decrease information asymmetry. Disseminating information in a report is one of the most useful transmission methods (annual financial reports and stability) (Ching et al., 2017). According to signaling theory, successful management communicates with stakeholders about the firm's commitment and long-term strategy on sustainability performance through corporate sustainability reports or corporate responsibility (Bae et al., 2018). Furthermore, sustainability reporting demonstrates good company governance, financial stability, an active environmental strategy, corporate social responsibility, climate change commitment, transparency, and overall connection with stakeholders. As a result, sent signals decrease information gaps between companies and their many stakeholders (internal and external) and give a competitive advantage by decreasing the legitimacy gap with society (Ching et al., 2017). Furthermore, stakeholder feedback signals are necessary for the company to comprehend the true distance between managers and stakeholders, as well as to promote the development and implementation of a better program to close that gap.

\section{Research background}

In research, Hemmati et al. (2019) found that a value-added social statement might be a useful report for assessing a company's economic, social, and environmental performance.

According to Rezaee and Tao (2019), the positive relationship between innate earnings quality and sustainability reporting quantity may be increased while the negative relationship between discretionary earnings quality and sustainability disclosure quantity can be decreased. Furthermore, their further research suggested that the relationship between earnings quality and sustainability disclosure quantity is influenced by corporate structure and prioryear sustainability performance.

After adjusting for numerous firm-specific variables, Alipour et al. (2019) discovered a substantial positive link between environmental reporting quality and earnings quality in research.

Abdi et al. (2020) categorized sustainability reporting factors into five primary types and 24 criteria in their analysis. Environmental requirements, corporate governance characteristics, and structural aspects of the company were ranked first among the sustainability reporting drivers by experts. The criteria of legal requirements, board member independence, and profitability 
ranked first and second, respectively, in the rating of the indicators. The criteria of legal requirements, board member independence, and profitability ranked first and second, respectively, in the rating of the indicators.

Moses et al. (2020) performed research in Malaysia to better understand the link between corporate governance mechanisms and the quality of sustainability reporting. They looked at how the quality of sustainability reporting affected the board's features. The findings demonstrated a favorable link between the aspects of corporate governance strategies and the quality of sustainability reporting, as predicted by numerous theories.

In a research, Correa-Garcia et al. (2020) looked at the elements that influence the quality of sustainability reporting in Latin American companies. The findings revealed that group control concentration had a detrimental impact on the quality of sustainability reporting. According to their findings, foreign ownership restrictions, the age of company groupings, and the size of the board of directors have all helped to improve the quality of sustainability reporting.

Khan et al. (2020) used the framework of the World Bank Report on Bangladesh's Banks to examine the quality of sustainability reporting and the influence of regulatory requirements, social performance, and a standard reporting structure. The quality of sustainability reporting improved when regulatory standards and social performance were measured using the GRI's criteria.

In a study of sustainability reporting in Italian public service firms, Badia et al. (2020) addressed the issue of quality. Despite the rising use of nonfinancial reporting in organizational life, their findings revealed that it is not widely used inside public services. They discussed the topic of sustainability reporting quality and came to the conclusion that non-financial reporting is generally accurate, clear, and comparable; timeliness and stakeholder participation appear to be acceptable, but reliability appears to be missing.

In his study, Al-shaer (2020) looked at data from FTSE 350 companies from 2007 to 2018 and found that companies that publish high-quality sustainability reports are both positively and negatively linked with profits management measures.

Adaui (2020) investigated the influence of new regulatory requirements for sustainability disclosure on the quality of sustainability reporting. Despite the introduction of new regulatory requirements, the quality of sustainability reporting continued to improve, according to the findings of the study. 
Jadoon et al. (2021) assessed the impact of sustainability reporting quality on sustainable corporate performance information content using data from 247 enterprises in 21 countries and the Green Economic Growth Index. The findings of the regression analysis revealed that the information content of sustainability performance derived from economic, social, and corporate governance components. Investors, on the other hand, saw the environmental performance as unimportant to boost the firm's worth. According to their findings, the quality of sustainability reporting has a significant impact on corporate governance information content. As a result, investors considered it as a new corporate governance tool.

\section{Population and Sample in Multi-Criteria Decision-Making}

Population and sample are two of the most important considerations in multicriteria decision-making. We started by defining the experts. Academics and management accounting and economics professionals with at least a master's degree are among the experts in this study. When the scope of the research involves a specific company or institution, the intentional sampling technique is utilized in Multi-Criteria Decision-Making (MCDM) procedures. Furthermore, education and experience are factors, and several specialists from that company are chosen as a sample (Habibi et al., 2014). The snowball sampling approach was selected since the scope of the current study is broader than an organization and encompasses a specific scientific subject such as the quality of sustainability reporting. In this research, 40 experts were employed in the Delphi stage and 10 in the subsequent phases.

\section{Data collection tools in Multi-Criteria Decision-Making methods}

Thurstone was the one who initially offered a few comparisons. According to Thurstone (1927), if a group's members are to be assessed fairly, they should be compared in pairs. To explain this, he introduced the word paired. Thomas Saati utilized the same methodology to assess the superiority of the items in each cluster when he developed the Analytic Hierarchy Process method. As a result, this questionnaire is also known as the paired comparison questionnaire. It's also known as the Expert Questionnaire since it's frequently used to evaluate expert opinions.

In multi-criteria decision-making procedures, a matrix is utilized to collect data, and the values are usually genuine statistics. Pairwise comparisons, as we'll discover if we pay attention to them, aren't statistical surveys. It's simply a mathematical matrix comprising comparing pairs of variables. As a result, pairwise comparisons are only a mathematical matrix 
The model for measuring the Quality of Sustainability Reporting...

with no statistical value, and the words attitude or attitude scale, such as the Thurston scale, are preferred. As a result, the pairwise comparison matrix's validity and reliability are useless because the questionnaire is not used. In the Analytic Hierarchy Process (AHP), the inconsistency rate is used to assess the validity of pairwise comparisons, whereas the reliability rate is utilized in the ANP based on Fuzzy DEMATEL (DANP). The paired comparisons were carried out logically and properly if the inconsistency and reliability rates were less than 0.1 and 0.05 , respectively (Tables $2-7$ ).

Table 2. Delphi Expert Opinions on Screening Criteria and Effective Factors

\begin{tabular}{|c|c|c|c|c|c|}
\hline Criteria & $\begin{array}{c}\text { Strongly } \\
\text { Disagree }\end{array}$ & Disagree & Neutral & Agree & $\begin{array}{c}\text { Strongly } \\
\text { Agree }\end{array}$ \\
\hline A & & & & & $\checkmark$ \\
\hline B & & & & $\checkmark$ & \\
\hline C & & & $\checkmark$ & & \\
\hline D & & $\checkmark$ & & & \\
\hline
\end{tabular}

Table 3. Likert scale for use in the Delphi method and related fuzzy numbers

\begin{tabular}{|c|c|c|c|c|c|}
\hline Scale & $\begin{array}{c}\text { Strongly } \\
\text { Disagree }\end{array}$ & Disagree & Neutral & Agree & $\begin{array}{c}\text { Strongly } \\
\text { Agree }\end{array}$ \\
\hline $\begin{array}{c}\text { Definite } \\
\text { number }\end{array}$ & 1 & 2 & 3 & 4 & 5 \\
\hline $\begin{array}{c}\text { Fuzzy } \\
\text { numbers }\end{array}$ & $(1.1 .1)$ & $(1.2 .3)$ & $(2.3 .4)$ & $(3.4 .5)$ & $(4.5 .6)$ \\
\hline
\end{tabular}

Table 4. Example of Expert Questionnaire Used in AHP Based on Thurston Attitude Scale (1927)

\begin{tabular}{|c|c|c|c|c|c|c|c|c|c|c|c|c|c|c|c|c|c|c|}
\hline \multirow{2}{*}{ Criteria } & \multicolumn{10}{|c|}{ Score } & \multirow{2}{*}{ Criteria $_{\mathrm{j}}$} \\
\hline & 9 & 8 & 7 & 6 & 5 & 4 & 3 & 2 & 1 & 2 & 3 & 4 & 5 & 6 & 7 & 8 & 9 & \\
\hline A & & & $\checkmark$ & & & & & & & & & & & & & & & B \\
\hline A & & & & $\checkmark$ & & & & & & & & & & & & & & C \\
\hline A & & & & & & & & & & & & & & & $\checkmark$ & & & D \\
\hline B & & & $\checkmark$ & & & & & & & & & & & & & & & C \\
\hline B & & & & & & & & & & & & & & & & $\checkmark$ & & D \\
\hline C & & & & & & & & & & & & & & & & & $\checkmark$ & D \\
\hline
\end{tabular}


Table 5. Basic Scale of Preferences for Judging the Saati Method and Related Fuzzy Numbers

\begin{tabular}{|c|c|c|c|c|c|c|c|c|c|}
\hline Scale & $\begin{array}{l}\stackrel{\lambda}{\bar{\Xi}} \\
\text { 壱 }\end{array}$ & 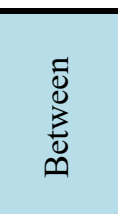 & $\begin{array}{l}\frac{\lambda}{\overrightarrow{0}} \\
\bar{\pi} \\
\frac{\overrightarrow{0}}{0} \\
\stackrel{0}{\Sigma}\end{array}$ & $\begin{array}{l}\text { ల్ల } \\
\sum_{0}^{0} \\
\infty\end{array}$ & $\begin{array}{l}\vec{\lambda} \\
\overrightarrow{0 D} \\
\overrightarrow{0} \\
\dot{E}\end{array}$ & $\begin{array}{l}\text { ల్ల } \\
\sum_{0}^{0} \\
\infty\end{array}$ & 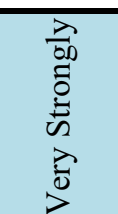 & 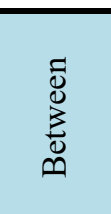 & 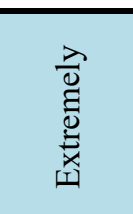 \\
\hline $\begin{array}{l}\text { Definite } \\
\text { number }\end{array}$ & 1 & 2 & 3 & 4 & 5 & 6 & 7 & 8 & 9 \\
\hline $\begin{array}{c}\text { Fuzzy } \\
\text { numbers }\end{array}$ & $(1.1 .1)$ & $(1.2 .3)$ & (2.3.4) & $(3.4 .5)$ & $(4.5 .6)$ & $(5.6 .7)$ & $(6.7 .8)$ & $(7.8 .9)$ & $(8.9 .10)$ \\
\hline
\end{tabular}

Table 6. Sample of Parallel Comparison Attitude Scale Based on DEMATEL Technique

\begin{tabular}{|c|c|c|c|c|}
\hline Criteria $_{\text {ij }}$ & $\mathrm{A}$ & $\mathrm{B}$ & $\mathrm{C}$ & $\mathrm{D}$ \\
\hline $\mathrm{A}$ & 0 & $(0.1 .2 .3 .4)$ & $(0.1 .2 .3 .4)$ & $(0.1 .2 .3 .4)$ \\
\hline $\mathrm{B}$ & $(0.1 .2 .3 .4)$ & 0 & $(0.1 .2 .3 .4)$ & $(0.1 .2 .3 .4)$ \\
\hline $\mathrm{C}$ & $(0.1 .2 .3 .4)$ & $(0.1 .2 .3 .4)$ & 0 & $(0.1 .2 .3 .4)$ \\
\hline $\mathrm{D}$ & $(0.1 .2 .3 .4)$ & $(0.1 .2 .3 .4)$ & $(0.1 .2 .3 .4)$ & 0 \\
\hline
\end{tabular}

Table 7: Scale of the effect of factors on each other based on the DEMATEL technique and related fuzzy numbers

\begin{tabular}{|c|c|c|c|c|c|}
\hline Scale & No & Very Low & Low & Hight & $\begin{array}{c}\text { Very } \\
\text { Hight }\end{array}$ \\
\hline Definite number & 0 & 1 & 2 & 3 & 4 \\
\hline Fuzzy numbers & $(0,0,0.25)$ & $(0,0.25,050)$ & $(0.25,0.50,0.75)$ & $(0.50,0.75,1)$ & $(0.75,1,1)$ \\
\hline
\end{tabular}

\section{The most important Determinants}

\section{Internal control reporting}

Internal control, as a monitoring tool, minimizes information asymmetry between firms and stakeholders by connecting them to markets. Successful internal control also improves the efficiency and quality of the information system. It also establishes a proper structure for dividing duties, monitoring, and power balance, eliminates conflicts of interest between corporations and stakeholders, and safeguards the rights and interests of stakeholders. This internal control also motivates companies to operate hard to enhance their corporate social responsibility performance $(\mathrm{Li}, 2020)$. Based on a sample of 1767 firms in China between 2011 and 2016, Li et al. (2018) found that 
sufficient internal control has pushed corporations to take on considerably higher social obligations.

\section{Sustainable innovation performance}

Sustainable innovation, according to Bos-Brouwers (2010), is described as the modernization or enhancement of technical or organizational goods, services, and processes that improve economic, environmental, and social performance in the short and long term. As a result, they have the potential to have good social and environmental consequences in the long run. Several patents are taken into account when calculating innovation performance, although generating new technology does not reflect its economic worth. Citations, as well as a large number of new products and patents, are important markers of technical innovation success (Acs et al., 2002). Jeong and Shin (2020) utilized the patents index to assess innovation success in their study on factors impacting corporate performance via sustainable innovation.

\section{Earnings Quality}

According to previous research, voluntary disclosures, such as sustainability reporting, can either replace or complement low-quality earnings and required financial reporting. As a result, this research confirms the complimentary link that high-profit firms tend to release more disclosures, which improves corporate reporting's trustworthiness and validity. To decrease earnings management and opportunistic behavior, Rezaee and Tao (2019) looked at the relationship between sustainability reporting quality and quantity earnings quality. Their findings show a positive link between the quantities of sustainability reporting and the quality of intrinsic earnings, but a negative relationship between the quality of sustainability reporting and the quality of intrinsic earnings. In addition, the significance of sustainability reporting quality in generating a favorable link between the quantity of sustainability reporting and the quality of revenues has been favorably assessed.

\section{Economic performance}

Tobin's q was utilized by Abdi et al. (2020) to represent a firm's performance to determine how the metric reacts to the firm's sustainability performance. The term "performance" in the study appears to be split into two distinct streams. First, this upbeat viewpoint asserts that environmental and social responsibility can coexist with increasing shareholder income and accomplishing larger societal objectives. According to Hill (2020), the adoption of sustainability 
disclosure has an influence on investment returns by affecting company financial performance as well as the dangers presented to broader economic development and financial market stability. On the other side, some argue that these behaviors are frequently a reflection of internal management agency issues and hence problematic. It's been demonstrated in a few studies with mixed outcomes (Xie et al., 2019). According to certain studies, sustainability efforts have a beneficial impact on firm performance (Fatemi et al., 2018). Other studies, on the other hand, find that sustainability has an impact on a company's success (Lee et al., 2009). Taking a deeper look at the topic, a study of 132 experimental publications performed in response to Alshahi et al. (2018) research found that more than 78 percent of these studies demonstrate a favorable link between firm stability and company financial success. Lourenco et al. (2012) assessed a favorable link between these two categories based on this debate and comparative studies. It's also worth noting that long-term sustainability may boost profitability by improving stakeholder connections and lowering the cost of engaging with them, as well as increasing staff credibility and productivity.

\section{Value Relevance}

The ability to assess performance to explain changes in contemporaneous stock returns is known as value relevance. It's an estimate of how beneficial it is to measure performance while making stock investment decisions. Financial information, such as sales, earnings, stock book value, comprehensive income, and operating cash flows, has traditionally been the emphasis of information content. Non-financial elements have become an important component in influencing stock values, according to a new stream of information content. It is stressed that accounting data is not the sole element that accounts for differences in company market value. Non-financial information, like financial information, has an impact on market value and change. As a result, nonfinancial research's informative substance focuses more on corporate sustainability performance and its dimensions (Aureli et al., 2020). This hypothesis includes quantitative and qualitative criteria as a major component in understanding stock price movements at the same time (Jadoon et al., 2021). 


\section{Conceptual model of research}

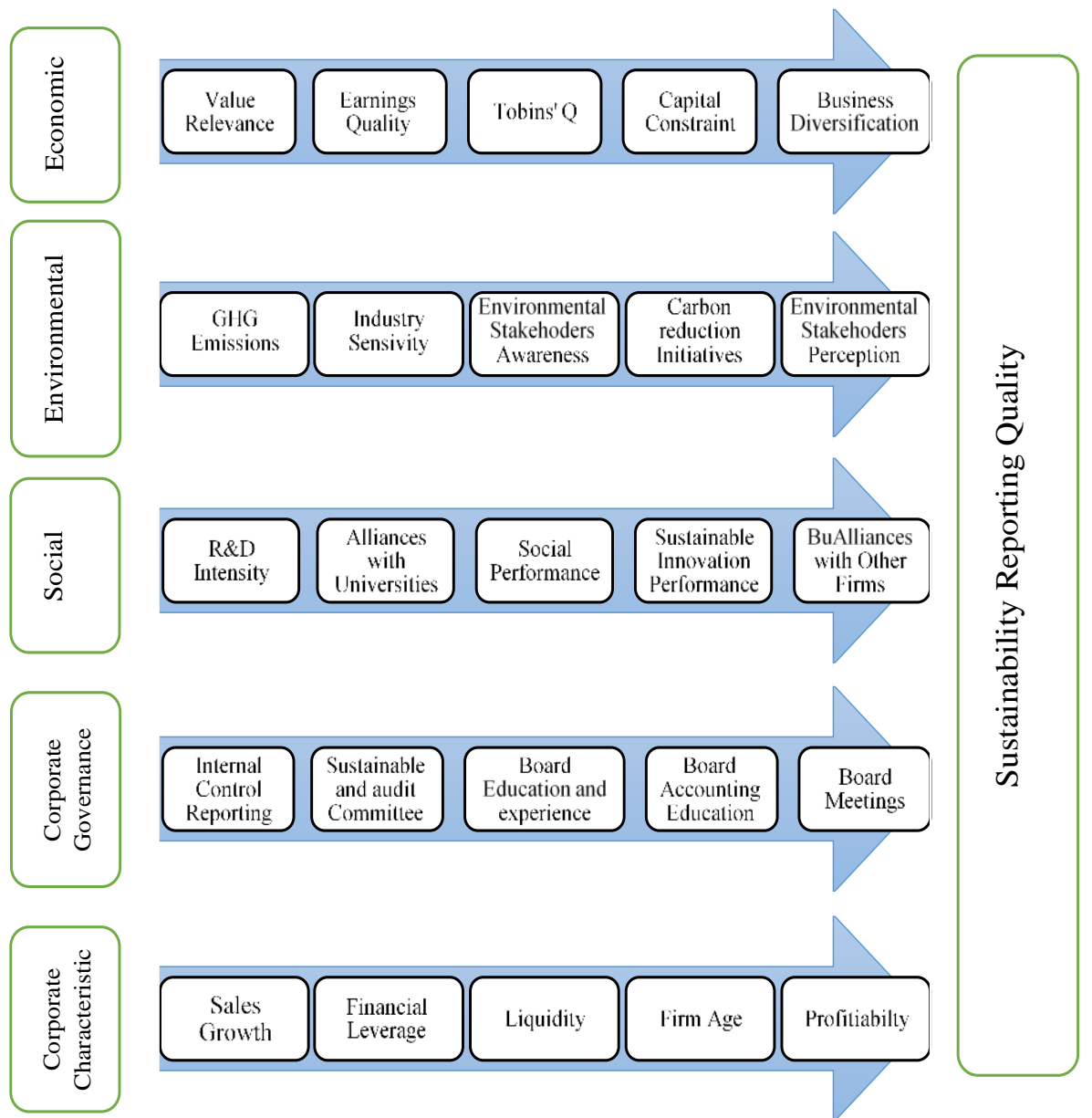

Figure 1. Conceptual framework of quality of sustainability reporting and the determinants

\section{Data analysis tool}

To give relevant information for decision-making, the Delphi approach is employed. The most important decision-making indicators may be identified and screened using this method. Although the Delphi method is not a multicriteria decision-making (MCDM) approach, it is frequently used to filter indications or achieve consensus on the relevance of indicators before MCDM techniques are applied. The collected criteria from the content analysis stage 
were given to 40 experts before applying multi-criteria decision-making approaches in this study. Furthermore, they measured their point of view using a five-point Likert scale (strongly disagree to strongly agree) supplied to them online using the Porsa site (IranDoc). The implementation of the Delphi technique yielded a Cronbach's alpha coefficient of 0.94, indicating dependability. As a result of using the Delphi technique to filter the criteria, a total of six criteria for measuring the quality of sustainability reporting and 25 criteria for determinants were chosen. Decision-making is defined as selecting a solution from a set of options. The MCDM is a large selection of operations research that assists managers in making decisions based on several competing factors. Several indications or aims, which are often conflicting, are evaluated in such judgments. Multi-attribute decision making occurs when the attribute is an indication in MCDM. The weight of the criterion was determined using the AHP, ANP, and DEMATEL methods. When many criteria represent a goal, this is referred to as multi-objective decision making. SAW, TOPSIS, and VIKOR techniques are also offered to choose the best choice based on the decision matrix.

\section{Fuzzy Analytic Hierarchy Process}

The FAHP is a fuzzy logic-based approach for paired comparison matrix analysis. Expert competencies and mental capacities are utilized to draw comparisons in the traditional Analytic Hierarchy Process technique. However, it should be highlighted that the typical pairwise comparison does not fully reflect the manner of human reasoning. Fuzzy numbers are more compatible with verbal and, at times, confusing human emotions. As a result, it is preferable to make judgments in the actual world using fuzzy numbers. Van Laarhoven and Pedrycz, two Dutch scholars, presented the Fuzzy Analytic Hierarchy Process technique for the first time in 1983. This technique works by inserting Triangular Fuzzy Numbers (TFN) into a matrix of pairwise comparisons based on the smallest logarithmic squares. Because of the complexities of the processes in this approach, it is rarely used. Following that, several techniques for the fuzzy Analytic Hierarchy Process were suggested. In his book Fuzzy Multi-Criteria Decision Making, Kahraman Cengiz describes the Fuzzy Analytic Hierarchy Process (Habibi et al., 2014). Regarding Kahraman, the Buckley technique was employed in the current investigation (Tables 8 and 9). 
The model for measuring the Quality of Sustainability Reporting...

Table 8. Example of pairwise comparison matrix based on Analytic Hierarchy Process (AHP)

\begin{tabular}{|c|c|c|c|c|}
\hline Criteria $_{i j}$ & A & B & $\mathrm{C}$ & D \\
\hline A & 1 & A to $B$ & A to $\mathrm{C}$ & A to $D$ \\
\hline $\mathrm{B}$ & $(A \text { to } B)^{-1}$ & 1 & B to $\mathrm{C}$ & B to D \\
\hline $\mathrm{C}$ & $(\text { A to } C)^{-1}$ & $(\mathrm{~B} \text { to } \mathrm{C})^{-1}$ & 1 & C to $D$ \\
\hline D & $(A \text { to } D)^{-1}$ & $(\mathrm{~B} \text { to } \mathrm{D})^{-1}$ & $(\mathrm{C} \text { to } \mathrm{D})^{-1}$ & 1 \\
\hline
\end{tabular}

Table 9. Random index (RI) scale for each matrix

\begin{tabular}{|c|c|c|c|c|c|c|c|c|c|c|}
\hline $\mathrm{N}$ & 1 & 2 & 3 & 4 & 5 & 6 & 7 & 8 & 9 & 10 \\
\hline $\mathrm{RI}_{\mathrm{m}}$ & 0 & 0 & 0.4890 & 0.7937 & 1.0720 & 1.1996 & 1.2874 & 1.3410 & 1.3793 & 1.4095 \\
\hline $\mathrm{RI}_{\mathrm{g}}$ & 0 & 0 & 0.1796 & 0.2627 & 0.3597 & 0.3818 & 0.4090 & 0.4164 & 0.4348 & 0.4455 \\
\hline
\end{tabular}

\section{Analytic Network Process based on Fuzzy DEMATEL}

This is the MCDM approach, in which the network has replaced the hierarchical structure and supports the two-way interaction between the criteria and their internal linkages. The DEMATL technique is likewise based on pairwise comparisons, which, using expert judgment and graph hypothesis principles, turns the cause-effect correlations between criteria into a tangible structure. The DEMATL technique may be coupled with the Analytic Network Process approach since it determines the cause-and-effect linkages between variables. The amount of reliance on the criteria in the network approach is two-way, which is not the case in the DEMATL technique, and it is closer to the actual world. To correct this flaw in the network, the full DEMATL connection matrix (TC) was constructed for the weight of the criterion (Table 10).

Table 10. Example pairwise comparison matrix based on DEMATEL technique

\begin{tabular}{|c|c|c|c|c|}
\hline Criteria $_{\mathrm{ij}}$ & A & B & C & D \\
\hline A & 0 & A on B & A on C & A on D \\
\hline B & B on A & 0 & B on C & B on D \\
\hline C & C on A & C on B & 0 & C on D \\
\hline D & D on A & D on B & D on C & 0 \\
\hline
\end{tabular}




\section{Research Findings}

\section{Descriptive statistics of experts and results of Delphi method}

The primary goal of this research is to demonstrate the model for assessing the quality of sustainability reporting and the factors that influence it. As a consequence, in the first step, the criteria and effective elements were identified, extracted, and first refined for this goal. Then, using the Likert attitude scale, 40 experts were given six criteria for evaluating the quality of sustainability reporting and 43 criteria for effective elements on the list via the Irandoc site and software named Porsa (Tables 11 and 13). These findings were used in subsequent phases.

Table 11. Descriptive statistics of experts participating in the Delphi screening stage (40 people)

\begin{tabular}{|c|c|c|c|c|}
\hline \multicolumn{2}{|c|}{ Main Category } & Subcategory & Number & Percent \\
\hline \multirow{2}{*}{\multicolumn{2}{|c|}{ Gender }} & Man & 34 & 0.850 \\
\hline & & Woman & 6 & 0.150 \\
\hline \multirow{2}{*}{\multicolumn{2}{|c|}{ Degree of education }} & $\mathrm{PhD}$ & 31 & 0.775 \\
\hline & & Master & 9 & 0.225 \\
\hline \multirow{3}{*}{\multicolumn{2}{|c|}{ Field of Study }} & Accounting & 32 & 0.800 \\
\hline & & Management and Economic & 4 & 0.100 \\
\hline & & Other & 4 & 0.100 \\
\hline \multirow{5}{*}{ Occupation } & \multirow{4}{*}{ Academics } & Full Professor & 2 & 0.050 \\
\hline & & Associate Professor & 7 & 0.175 \\
\hline & & Assistant Professor & 19 & 0.475 \\
\hline & & Instructor & 2 & 0.050 \\
\hline & Other & & 10 & 0.250 \\
\hline \multirow{2}{*}{\multicolumn{2}{|c|}{ Professionals }} & $\mathrm{CPA}$ & 5 & 0.125 \\
\hline & & Justice Experts & 1 & 0.025 \\
\hline
\end{tabular}

Table 12. Sustainability Reporting Quality's Measures according to content analysis and Delphi survey

\begin{tabular}{|c|c|c|}
\hline SRQ Measures: & Sign & Weights \\
\hline Disclosure checklist according to reporting and disclosure in Iran & $\mathrm{C}_{1}$ & 0.17143 \\
\hline GRI Foundation Reporting Principles Checklist & $\mathrm{C}_{2}$ & 0.17117 \\
\hline $\begin{array}{c}\text { GRI Standards Disclosure Checklist for Sustainability Reporting } \\
\text { Checklist }\end{array}$ & $\mathrm{C}_{3}$ & 0.16938 \\
\hline $\begin{array}{c}\text { Sustainability Reporting Assurance coding based on auditing firms or } \\
\text { accounting firms }\end{array}$ & $\mathrm{C}_{4}$ & 0.16698 \\
\hline $\begin{array}{c}\text { Deloitte Audit Model (Background, Content, Form, and Assurance \& } \\
\text { Reliability) }\end{array}$ & $\mathrm{C}_{5}$ & 0.16565 \\
\hline If the firm prepare the sustainability report, equal 1; zero otherwise & $\mathrm{C}_{6}$ & 0.15539 \\
\hline
\end{tabular}


The model for measuring the Quality of Sustainability Reporting...

Table 13. Sustainability Reporting Quality's Determinants according to content analysis and Delphi survey

\begin{tabular}{|c|c|c|c|c|c|c|}
\hline $\begin{array}{c}\mathrm{R} \\
\mathrm{o} \\
\mathrm{W}\end{array}$ & $\begin{array}{c}\text { Dime } \\
\text { nsion } \\
\mathrm{s}\end{array}$ & $\begin{array}{l}\text { Ques } \\
\text { tions }\end{array}$ & Criteria & $\begin{array}{l}\text { Wei } \\
\text { ghts }\end{array}$ & $\begin{array}{l}\mathrm{Ra} \\
\mathrm{nk}\end{array}$ & $\begin{array}{c}\mathrm{Si} \\
\mathrm{g} \\
\mathrm{n}\end{array}$ \\
\hline 1 & \multirow{5}{*}{ 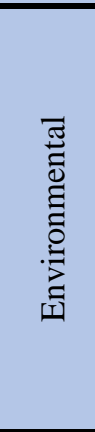 } & Q 8 & $\begin{array}{l}\text { Carbon performance (Outcome-based measurement): } \\
\text { GHG Emissions }\end{array}$ & $\begin{array}{r}0.02 \\
565\end{array}$ & 1 & $\begin{array}{l}\mathrm{C} \\
2\end{array}$ \\
\hline 2 & & Q 6 & $\begin{array}{l}\text { Industry Sensitivity: A high pollution industry } \\
\text { (chemical, oil, gas and pharmaceutical) }\end{array}$ & $\begin{array}{r}0.02 \\
557\end{array}$ & 2 & $\begin{array}{l}\mathrm{C} \\
3\end{array}$ \\
\hline 3 & & Q 5 & $\begin{array}{l}\text { Environmental Awareness: initiatives' reports to } \\
\text { reduce, reuse, substitute, or phase-out TCS }\end{array}$ & $\begin{array}{r}0.02 \\
490\end{array}$ & 3 & $\mathrm{C}$ \\
\hline 4 & & Q 3 & $\begin{array}{c}\text { Carbon performance: Process-based measurement } \\
\text { Carbon Reduction Initiatives }\end{array}$ & $\begin{array}{l}0.02 \\
466 \\
\end{array}$ & 4 & $\begin{array}{l}\mathrm{C} \\
5 \\
\end{array}$ \\
\hline 5 & & Q 2 & $\begin{array}{l}\text { Investor Perceptions: Certain environmental crucial } \\
\text { legal information (litigations, lawsuits, arbitrations) }\end{array}$ & $\begin{array}{l}0.02 \\
377\end{array}$ & 5 & $\begin{array}{l}\mathrm{C} \\
6 \\
\end{array}$ \\
\hline 11 & \multirow{5}{*}{ 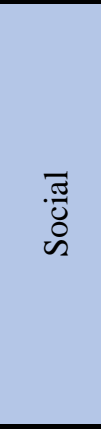 } & Q 4 & R\&D investment: $R \& D$ intensity & $\begin{array}{r}0.02 \\
457 \\
\end{array}$ & 1 & $\begin{array}{l}\mathrm{C} \\
7 \\
\end{array}$ \\
\hline 12 & & Q 5 & $\begin{array}{l}\text { Firms' cooperation with universities: Alliances with } \\
\text { universities }\end{array}$ & $\begin{array}{l}0.02 \\
433 \\
\end{array}$ & 2 & $\begin{array}{l}\mathrm{C} \\
8\end{array}$ \\
\hline 13 & & Q 7 & Social Performance: CSR expenditures & $\begin{array}{l}0.02 \\
399\end{array}$ & 3 & C \\
\hline 14 & & Q 3 & Firms' sustainable innovation performance: patent & $\begin{array}{l}0.02 \\
398\end{array}$ & 4 & $\begin{array}{l}\mathrm{C} \\
10\end{array}$ \\
\hline 15 & & Q 2 & $\begin{array}{l}\text { Firms' cooperation with other firms: Alliances with } \\
\text { other firms }\end{array}$ & $\begin{array}{l}0.02 \\
365 \\
\end{array}$ & 5 & C \\
\hline 6 & \multirow{5}{*}{ 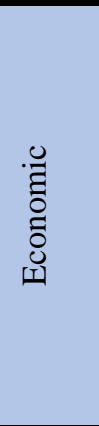 } & Q 2 & Value Relevance & $\begin{array}{l}0.02 \\
370 \\
\end{array}$ & 1 & $\begin{array}{l}\mathrm{C} \\
12\end{array}$ \\
\hline 7 & & Q 1 & Earnings Quality & $\begin{array}{l}0.02 \\
339\end{array}$ & 2 & $\mathrm{C}$ \\
\hline 8 & & Q 5 & Firms 'Economic Performance: Tobin's Q Index & $\begin{array}{l}0.02 \\
290\end{array}$ & 3 & $\begin{array}{l}\mathrm{C} \\
14\end{array}$ \\
\hline 9 & & Q 4 & Capital Constraints & $\begin{array}{l}0.02 \\
267 \\
\end{array}$ & 4 & $\begin{array}{l}\mathrm{C} \\
15\end{array}$ \\
\hline 10 & & Q 3 & Business Diversification & $\begin{array}{l}0.02 \\
228 \\
\end{array}$ & 5 & $\begin{array}{l}\mathrm{C} \\
16 \\
\end{array}$ \\
\hline 16 & \multirow{5}{*}{ 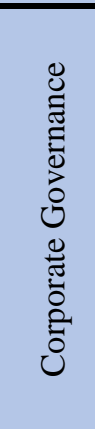 } & Q 6 & Internal Controls disclosure & $\begin{array}{r}0.02 \\
671 \\
\end{array}$ & 1 & $\begin{array}{l}\mathrm{C} \\
17\end{array}$ \\
\hline 17 & & Q 7 & $\begin{array}{c}\text { Existence of sustainability, Environmental, CSR, Risk, } \\
\text { Reward, and Audit committees }\end{array}$ & $\begin{array}{r}0.02 \\
619\end{array}$ & 2 & $\begin{array}{l}\mathrm{C} \\
18\end{array}$ \\
\hline 18 & & Q 1 & Board Higher Education and Experience & $\begin{array}{l}0.02 \\
465 \\
\end{array}$ & 3 & $\begin{array}{l}\mathrm{C} \\
19 \\
\end{array}$ \\
\hline 19 & & Q 4 & Board Financial education & $\begin{array}{l}0.02 \\
435 \\
\end{array}$ & 4 & $\begin{array}{l}\mathrm{C} \\
20 \\
\end{array}$ \\
\hline 20 & & Q 9 & Board Meeting: Number of board meetings per year & $\begin{array}{r}0.02 \\
402\end{array}$ & 5 & $\begin{array}{l}\mathrm{C} \\
21\end{array}$ \\
\hline
\end{tabular}


Iranian Journal of Finance, 2022, Vol. 6, No. 2 (Esmaeilzadeh, H.)

\begin{tabular}{|c|c|c|c|c|c|c|}
\hline 21 & 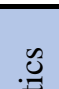 & Q 4 & Sales Growth :Growth Opportunities & $\begin{array}{l}0.02 \\
532\end{array}$ & 1 & $\begin{array}{l}\mathrm{C} \\
22\end{array}$ \\
\hline 22 & 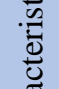 & Q 3 & Financial Leverage: Total Debts/ Total Assets & $\begin{array}{l}0.02 \\
450\end{array}$ & 2 & $\begin{array}{l}\mathrm{C} \\
23 \\
\end{array}$ \\
\hline 23 & 苛 & Q 7 & Liquidity: Current Ratio= CA/CB & $\begin{array}{l}0.02 \\
431\end{array}$ & 3 & $\begin{array}{l}\mathrm{C} \\
24 \\
\end{array}$ \\
\hline 24 & $\begin{array}{l}\text { 节 } \\
\text { : }\end{array}$ & Q 1 & $\begin{array}{l}\text { Firm Age: The number of years since incorporation to } \\
\text { date }\end{array}$ & $\begin{array}{l}0.02 \\
385\end{array}$ & 4 & $\mathrm{C}$ \\
\hline 25 & ठี & Q 2 & Profitability: ROA, ROE, P/E, CFO/Net Income & $\begin{array}{l}0.02 \\
361\end{array}$ & 5 & $\mathrm{C}$ \\
\hline
\end{tabular}

\section{Results of the Fuzzy Analytic Hierarchy Process (FAHP)}

AHP's computation is dependent on the decision-initial maker's assessment, which is represented via a pairwise comparison matrix. As a result, any mistakes or inconsistencies in comparing the parts have an impact on the final computation result. The discrepancy rate in this approach suggests that the data obtained can be believed from each expert's standpoint. In Table 13, the experts' inconsistency rates are less than 0.1 , indicating pairwise comparisons are reliable. Expert views were combined once the discrepancy rate was calculated (Tables 13 - 16).

The outcomes of the FAHP application are also shown in Table 17. In this procedure, several ways of analysis are utilized, one of the most well-known of which is the Buckley geometric mean approach. GRI's principles for sustainability reporting checklist was ranked first based on these findings. The GRI's sustainability reporting standards came second. If the company prepares the sustainability report, it receives a score of 1; otherwise, it receives a score of 0 . The Disclosure checklist, on the other hand, was placed fifth in terms of reporting and disclosure in Iran, and the Deloitte Auditing Institute's model was ranked sixth (Tables 16 - 17).

Table 14. Consistency rate (CR) of expert pairwise comparisons using AHP technique

\begin{tabular}{|c|c|c|c|c|c|c|c|c|c|c|}
\hline Expert & 1 & 2 & 3 & 4 & 5 & 6 & 7 & 8 & 9 & 10 \\
\hline $\mathrm{CR}^{\mathrm{m}}$ & 0.032 & 0.035 & 0.026 & 0.042 & 0.032 & 0.049 & 0.035 & 0.033 & 0.044 & 0.028 \\
\hline $\mathrm{CR}^{\mathrm{g}}$ & 0.087 & 0.078 & 0.063 & 0.080 & 0.094 & 0.095 & 0.086 & 0.070 & 0.097 & 0.055 \\
\hline
\end{tabular}


The model for measuring the Quality of Sustainability Reporting...

Table 15. Matrix of the geometric mean of experts

\begin{tabular}{|c|c|c|c|c|c|c|c|c|c|c|c|c|c|c|c|c|c|c|}
\hline \multirow{2}{*}{$\begin{array}{c}\text { Crite } \\
\text { ria }\end{array}$} & \multicolumn{3}{|c|}{$\mathrm{C}_{1}$} & \multicolumn{3}{|c|}{$\mathrm{C}_{2}$} & \multicolumn{3}{|c|}{$\mathrm{C}_{3}$} & \multicolumn{3}{|c|}{$\mathrm{C}_{4}$} & \multicolumn{3}{|c|}{$\mathrm{C}_{5}$} & \multicolumn{3}{|c|}{$\mathrm{C}_{6}$} \\
\hline & $\mathrm{L}$ & M & $\mathrm{U}$ & $\mathrm{L}$ & $\mathrm{M}$ & $\mathrm{U}$ & $\mathrm{L}$ & M & $\mathrm{U}$ & L & M & $\mathrm{U}$ & $\mathrm{L}$ & M & $\mathrm{U}$ & $\mathrm{L}$ & M & $\mathrm{U}$ \\
\hline $\mathrm{C}_{1}$ & $\stackrel{8}{8}$ & $\stackrel{8}{\circ}$ & $\stackrel{8}{8}$ & 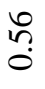 & $\begin{array}{l}\widetilde{\infty} \\
0 \\
0\end{array}$ & $\stackrel{?}{\longrightarrow}$ & $n$ & 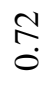 & ă & $\stackrel{\Re}{\tilde{o}}$ & & $\bar{m}$ & $\stackrel{m}{\circ}$ & $\hat{\vartheta}$ & $\stackrel{\text { }}{\vec{r}}$ & กี & $\stackrel{\bullet}{:}$ & $\begin{array}{l}+ \\
\stackrel{0}{0} \\
0\end{array}$ \\
\hline $\mathrm{C}_{2}$ & $\begin{array}{l}\hat{\infty} \\
0\end{array}$ & $\stackrel{\overbrace{}}{\stackrel{n}{S}}$ & $\stackrel{\infty}{\stackrel{\infty}{\xi}}$ & $\underset{.}{8}$ & $\underset{8}{8}$ & $\underset{-}{8}$ & \begin{tabular}{l}
$\stackrel{0}{\infty}$ \\
\hdashline
\end{tabular} & $\stackrel{\overbrace{}}{\rightarrow}$ & $\stackrel{m}{\stackrel{r}{r}}$ & $\stackrel{\Omega}{o}$ & 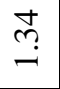 & 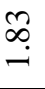 & $\stackrel{\overbrace{}}{\overbrace{}}$ & $\hat{a}$ & $\begin{array}{l}\widetilde{\sigma} \\
\text { i. }\end{array}$ & $\stackrel{\infty}{0}$ & ले & $\stackrel{?}{=}$ \\
\hline $\mathrm{C}_{3}$ & $\stackrel{\text { }}{\circ}$ & $\stackrel{\infty}{\dddot{m}}$ & $\stackrel{\substack{\infty \\
\infty}}{ }$ & $\begin{array}{l}\infty \\
n \\
n\end{array}$ & $\begin{array}{l}\bar{\infty} \\
0\end{array}$ & $\stackrel{\overbrace{}}{\Im}$ & $\stackrel{8}{8}$ & $\stackrel{8}{.}$ & $\stackrel{\text { }}{.}$ & $\begin{array}{l}+ \\
\infty \\
0\end{array}$ & $\stackrel{\overbrace{}}{\underline{-}}$ & & ô. & oे & 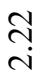 & oे. & $\underset{-}{\stackrel{\Delta}{0}}$ & f \\
\hline $\mathrm{C}_{4}$ & $\stackrel{\hat{\sigma}}{0}$ & ప઼ & $\stackrel{\infty}{m}$ & ñ. & $\stackrel{n}{\stackrel{n}{0}}$ & $\stackrel{\infty}{\circ}$ & $\stackrel{8}{8}$ & $\begin{array}{l}\bar{\infty} \\
0 \\
0\end{array}$ & $\stackrel{\text { Iִ }}{\text { }}$ & $\underset{-}{8}$ & $\underset{-}{\&}$ & $\underset{.}{8}$ & б̆ & $\stackrel{\infty}{\stackrel{0}{\circ}}$ & $\stackrel{\overbrace{}}{\overbrace{}}$ & $\stackrel{t}{0}$ & $\stackrel{n}{\stackrel{n}{0}}$ & $\bar{\sigma}$ \\
\hline $\mathrm{C}_{5}$ & $\stackrel{ }{\stackrel{0}{0}}$ & $\hat{o}$ & $\stackrel{n}{n}$ & $\begin{array}{c}\infty \\
\stackrel{m}{n} \\
0\end{array}$ & $\tilde{n}$ & $\begin{array}{l}\bar{\infty} \\
0\end{array}$ & $\stackrel{?}{\stackrel{2}{0}}$ & ñ? & $\hat{\sigma}$ & $\frac{?}{i}$ & $\hat{\sigma}$ & $\stackrel{\infty}{\stackrel{\infty}{\circ}}$ & $\underset{.}{8}$ & $\stackrel{8}{.}$ & $\underset{.}{8}$ & $\stackrel{\stackrel{\leftrightarrow}{+}}{0}$ & $\begin{array}{l}\bar{\sigma} \\
0\end{array}$ & $\begin{array}{l}\infty \\
0\end{array}$ \\
\hline $\mathrm{C}_{6}$ & $\stackrel{\vartheta}{\rightleftarrows}$ & $\stackrel{n}{n}$ & $\widehat{\sigma}$ & $\stackrel{\infty}{n}$ & $\stackrel{\mathbb{N}}{0}$ & $\underset{-}{\sigma}$ & $\begin{array}{l}\infty \\
: \\
0\end{array}$ & 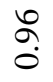 & $\stackrel{\text { If }}{-}$ & $\stackrel{\varrho}{=}$ & $\stackrel{\oplus}{m}$ & ñ & $\stackrel{\overbrace{}}{\stackrel{\vartheta}{~}}$ & ț & $\begin{array}{l}\stackrel{8}{0} \\
\text { i }\end{array}$ & $\stackrel{8}{8}$ & $\stackrel{8}{\circ}$ & $\stackrel{8}{8}$ \\
\hline
\end{tabular}

Table 16. Ranking matrix of quality measurement criteria for sustainability reporting based on Buckley method

\begin{tabular}{|c|c|c|c|c|c|c|c|c|c|c|c|c|c|c|c|c|c|c|c|c|c|c|c|c|}
\hline \multirow{2}{*}{. } & \multicolumn{3}{|c|}{$\mathrm{C} 1$} & & \multicolumn{3}{|c|}{ C3 } & \multicolumn{3}{|c|}{$\mathrm{C} 4$} & \multicolumn{3}{|c|}{ C5 } & \multicolumn{3}{|c|}{ C6 } & \multicolumn{3}{|c|}{$\begin{array}{l}\text { Geo - } \\
\text { mean }\end{array}$} & & \multirow{2}{*}{$\begin{array}{l}\frac{0}{2} \\
\frac{.00}{0.0} \\
\frac{.0}{3}\end{array}$} & \multirow{2}{*}{$\mid \begin{array}{l}\text { चै } \\
\text { Е }\end{array}$} \\
\hline & $\mathrm{L}$ & $\mathrm{M}$ & $\mathrm{U}$ & $\mathrm{L}$ & $\mathrm{M}$ & $\mathrm{U}$ & $\mathrm{L}$ & $\mathbf{M}$ & $\mathrm{U}$ & $\mathrm{L}$ & $\mathrm{M}$ & $\mathrm{U}$ & $\mathrm{L}$ & $\mathrm{M}$ & $\mathrm{U}$ & $\mathrm{L}$ & $\mathrm{M}$ & $\mathrm{U}$ & L & $\mathrm{M}$ & $\mathrm{U}$ & & & \\
\hline $\mathrm{C}$ & $\stackrel{8}{8}$ & $\stackrel{8}{.}$ & $\stackrel{8}{8}$ & $\begin{array}{l}\text { ?ִ } \\
\text { ñ }\end{array}$ & $\begin{array}{c}\tilde{C} \\
0 \\
0\end{array}$ & $\stackrel{n}{=}$ & $\begin{array}{l}n \\
n \\
n \\
0\end{array}$ & $\stackrel{\mathbb{N}}{\tilde{O}}$ & ô. & $\begin{array}{l}0 \\
\tilde{0}\end{array}$ & 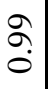 & $\vec{m}$ & $\stackrel{n}{o}$ & ع. & ले & ñ. & $\begin{array}{l}8 \\
: \\
0\end{array}$ & \begin{tabular}{l} 
\pm \\
$\infty$ \\
0 \\
\hdashline
\end{tabular} & $\begin{array}{l}\infty \\
0 \\
0 \\
0\end{array}$ & $\stackrel{ \pm}{0}$ & $\stackrel{\overbrace{}}{0}$ & $\begin{array}{l}n \\
0\end{array}$ & $\stackrel{ \pm}{0}$ & 5 \\
\hline $\begin{array}{l}\mathrm{C} \\
2\end{array}$ & $\begin{array}{c}\infty \\
\infty \\
\infty\end{array}$ & $\stackrel{\overbrace{}}{\rightarrow}$ & 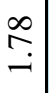 & 8 & $\stackrel{8}{8}$ & $\stackrel{8}{.}$ & $\begin{array}{c}0 \\
\infty \\
\vdots \\
0\end{array}$ & $\stackrel{\overbrace{}}{-}$ & $\stackrel{?}{\stackrel{?}{i}}$ & $\hat{\sigma}$ & $\stackrel{\oplus}{m}$ & $\stackrel{\infty}{\infty}$ & $\stackrel{\overbrace{}}{\rightarrow}$ & $\underline{\underline{i}}$ & $\begin{array}{l}\hat{6} \\
i\end{array} \mid$ & $\begin{array}{l}\infty \\
\stackrel{0}{0}\end{array}$ & ફે. & $\stackrel{?}{\stackrel{?}{-}}$ & $\stackrel{1}{\circ}$ & तู & ల్రి & ֶָ. & 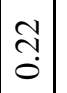 & 1 \\
\hline $\begin{array}{l}\mathrm{C} \\
3\end{array}$ & $\stackrel{8}{\circ}$ & $\stackrel{\infty}{\dddot{m}}$ & $\stackrel{\infty}{\infty}$ & $\stackrel{\infty}{?}$ & $\begin{array}{l}\bar{\infty} \\
0 \\
0\end{array}$ & $\stackrel{n}{\stackrel{n}{s}}$ & $\stackrel{8}{-}$ & 8 & 8 & $\begin{array}{l}+ \\
\infty \\
0 \\
0\end{array}$ & $\stackrel{\overbrace{}}{\stackrel{-}{\longrightarrow}}$ & : & ô. & $\stackrel{0}{\vec{b}}$ & $\begin{array}{c}\tilde{N} \\
\mathrm{i}\end{array}$ & $\begin{array}{l}0 \\
\dot{0} \\
0\end{array}$ & $\stackrel{+}{0}$ & $\stackrel{f}{\Im}$ & $\overrightarrow{0}$ & $\stackrel{2}{0}$ & $\tilde{3}$ & તి. & $\frac{9}{0}$ & 2 \\
\hline $\begin{array}{l}\mathrm{C} \\
4\end{array}$ & $\stackrel{\Sigma}{\circ}$ & $\stackrel{\overrightarrow{0}}{-}$ & 文 & nn & $\frac{n}{o}$ & $\stackrel{\infty}{\circ}$ & $\stackrel{8}{:}$ & $\begin{array}{l}\bar{\infty} \\
\infty \\
\dot{0}\end{array}$ & ָุ & $\stackrel{8}{8}$ & $\stackrel{8}{-}$ & 8 & ô & $\stackrel{\infty}{\circ}$ & $\stackrel{\overbrace{}}{-}$ & $\begin{array}{l}\mathbb{1} \\
\dot{0} \\
0\end{array}$ & $\begin{array}{l}n \\
0 \\
0\end{array}$ & $\bar{\sigma}$ & $\stackrel{0}{0}$ & $\frac{n}{0}$ & 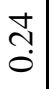 & $\begin{array}{l}0 \\
0 \\
0\end{array}$ & $\frac{n}{0}$ & 4 \\
\hline $\mathrm{C}$ & $\stackrel{N}{0}$ & $\hat{a}$ & $\hat{n}$ & $\stackrel{\infty}{n}$ & $\bar{n}$ & $\begin{array}{l}\infty \\
0 \\
0\end{array}$ & $\stackrel{9}{\circ}$ & ڤึ. & $\hat{\sigma}$ & $\begin{array}{l}0 \\
\stackrel{0}{0}\end{array}$ & $\delta$ & $\begin{array}{l}\infty \\
\stackrel{\infty}{0} \\
- \\
-1\end{array}$ & 8 & $\stackrel{8}{8}$ & $\underset{-}{8}$ & 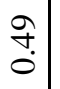 & $\begin{array}{l}\bar{b} \\
\dot{0}\end{array}$ & $\begin{array}{l}\bar{\infty} \\
0 \\
\dot{0}\end{array}$ & $\begin{array}{l}\infty \\
0 \\
0 \\
0\end{array}$ & $\stackrel{?}{\circ}$ & $\overrightarrow{\widetilde{o}}$ & $\frac{9}{0}$ & $\stackrel{1}{0}$ & 6 \\
\hline C & $\stackrel{9}{\rightrightarrows}$ & $\sqrt[n]{n}$ & 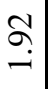 & ?n & $\stackrel{2}{2}$ & ฮै & $\infty$ & $\stackrel{0}{\circ}$ & $\stackrel{f}{\stackrel{f}{*}}$ & ? & $\stackrel{\oplus}{m}$ & ñ. & $\stackrel{\overbrace{}}{\stackrel{n}{~}}$ & $\begin{array}{l}\stackrel{t}{0} \\
\stackrel{-}{-}\end{array}$ & $\begin{array}{l}8 \\
\dot{i} \\
\text { in }\end{array}$ & 8 & 8 & $\underset{-}{8}$ & $\stackrel{1}{\circ}$ & $\frac{9}{0}$ & लే & กิ & $\frac{9}{0}$ & 3 \\
\hline
\end{tabular}


Table 17. FAHP Results (Sustainability Reporting Quality Assessment Measures)

\begin{tabular}{|c|c|c|c|}
\hline \multirow[t]{2}{*}{ SRQ Measures: } & \multirow[t]{2}{*}{ Sign } & \multicolumn{2}{|c|}{ Weights } \\
\hline & & Delphi & FAHP \\
\hline $\begin{array}{l}\text { GRI Foundation Reporting Principles Checklist for defining } \\
\text { reporting quality }\end{array}$ & $\mathrm{C}_{2}$ & 0.17136 & 0.21526 \\
\hline $\begin{array}{c}\text { GRI Standards Disclosure Checklist for Sustainability Reporting } \\
\text { Checklist }\end{array}$ & $\mathrm{C}_{3}$ & 0.17377 & 0.18936 \\
\hline The Al-shaer's model (2020) & $\mathrm{C}_{6}$ & 0.15422 & 0.18709 \\
\hline The model used by Rezaee and Tao (2019); Al-shaer (2020) & $\mathrm{C}_{4}$ & 0.16453 & 0.14593 \\
\hline Disclosure checklist according to reporting and disclosure in Iran & $\mathrm{C}_{1}$ & 0.16973 & 0.13920 \\
\hline Deloitte Auditing Institute's Model & $\mathrm{C}_{5}$ & 0.16638 & 0.12316 \\
\hline
\end{tabular}

\section{Analytic Network Process technique based on Fuzzy DEMATEL Result}

We suggest utilizing two multi-criteria decision-making approaches in the second stage: the fuzzy DEMATEL method for identifying internal connections between model components and the ANP method for weighting model criteria. This research also suggests the creation of a fuzzy inference system. The quality of sustainability reporting is evaluated using a systematic qualitative assessment approach described in this study. In such an examination, this approach can help select the most important elements. The total degree of quality reporting of any firm's sustainability may be assessed based on these variables. Tables 18 to 21 also included the findings of the DANP method. Internal connections based on the intensity of the threshold retrieved from the final DEMATEL matrix are also shown in Table 22. The coefficients in models No. 1 and 2 that are extracted from Tables No. 20 - 22

Model No. 1: Effective dimensions in the quality of sustainability reporting

$\gamma=\beta_{1} x_{1}+\beta_{2} x_{2}+\beta_{3} x_{3}+\beta_{3} x_{4}+\beta_{4} x_{5}$

$Y_{D}=0.04018 x_{1}+0.03991 x_{2}+0.03859 x_{3}+0.03773 x_{4}+0.03525 x_{5}$

Model No. 2: Factors Affecting the Quality of Sustainability Reporting

$\gamma=\alpha_{1} x_{1}+\alpha_{2} x_{2}+\alpha_{3} x_{3}+\alpha_{3} x_{4}+\alpha_{4} x_{5}$

$Y_{C}=0.04111 x_{1}+0.04104 x_{2}+0.04091 x_{3}+0.04060 x_{4}+0.04059 x_{5}$ 
The model for measuring the Quality of Sustainability Reporting...

Table 18. DEMATEL initial matrix of expert opinions merged with arithmetic mean

\begin{tabular}{|c|c|c|c|c|c|c|c|c|c|c|c|c|c|c|c|c|c|c|c|c|c|c|c|c|c|c|}
\hline $\begin{array}{c}\mathrm{Cr} \\
\text { ite } \\
\text { ri } \\
\mathrm{a}_{\mathrm{ij}}\end{array}$ & $\begin{array}{l}\mathrm{C} \\
1\end{array}$ & $\begin{array}{l}\mathrm{C} \\
2\end{array}$ & $\begin{array}{l}\mathrm{C} \\
3\end{array}$ & C & C & $\begin{array}{l}\mathrm{C} \\
6\end{array}$ & $\begin{array}{l}\mathrm{C} \\
7\end{array}$ & $\begin{array}{l}\mathrm{C} \\
8\end{array}$ & $\begin{array}{l}\mathrm{C} \\
9\end{array}$ & $\begin{array}{l}\mathrm{C} \\
1 \\
0\end{array}$ & $\begin{array}{l}\mathrm{C} \\
1 \\
1\end{array}$ & $\begin{array}{l}\mathrm{C} \\
1 \\
2\end{array}$ & $\begin{array}{l}\mathrm{C} \\
1 \\
3\end{array}$ & $\begin{array}{l}\mathrm{C} \\
1 \\
4\end{array}$ & & $\begin{array}{l}\mathrm{C} \\
1 \\
6\end{array}$ & $\begin{array}{c}\mathrm{C} \\
1 \\
7\end{array}$ & \begin{tabular}{|l}
$\mathrm{C}$ \\
1 \\
8
\end{tabular} & $\begin{array}{l}\mathrm{C} \\
1 \\
9\end{array}$ & $\begin{array}{l}\mathrm{C} \\
2 \\
0\end{array}$ & $\begin{array}{l}\mathrm{C} \\
2 \\
1\end{array}$ & $\begin{array}{l}\mathrm{C} \\
2 \\
2\end{array}$ & $\begin{array}{l}\mathrm{C} \\
2 \\
3\end{array}$ & $\begin{array}{l}\mathrm{C} \\
2 \\
4\end{array}$ & $\begin{array}{l}\mathrm{C} \\
2 \\
5\end{array}$ & \begin{tabular}{|l} 
C \\
2 \\
6
\end{tabular} \\
\hline $\mathrm{C}_{1}$ & $\begin{array}{l}0 \\
0 \\
0\end{array}$ & $\begin{array}{l}3 \\
4 \\
4\end{array}$ & $\begin{array}{l}3 \\
2 \\
2\end{array}$ & 3 & 0 & $\begin{array}{l}3 \\
5 \\
1\end{array}$ & $\begin{array}{l}2 \\
. \\
7\end{array}$ & $\begin{array}{l}2 \\
9 \\
9\end{array}$ & $\begin{array}{l}2 \\
8 \\
8\end{array}$ & $\begin{array}{l}3 \\
0\end{array}$ & $\begin{array}{l}2 \\
8 \\
8\end{array}$ & $\begin{array}{l}3 \\
\\
1\end{array}$ & $\begin{array}{l}3 \\
2 \\
2\end{array}$ & $\begin{array}{l}3 \\
2\end{array}$ & $\begin{array}{l}2 \\
. \\
9\end{array}$ & $\begin{array}{l}2 \\
. \\
9\end{array}$ & $\begin{array}{l}3 \\
. \\
0\end{array}$ & $\begin{array}{l}2 \\
6\end{array}$ & $\begin{array}{l}2 \\
2 \\
2\end{array}$ & $\begin{array}{l}2 \\
2 \\
2\end{array}$ & $\begin{array}{l}2 \\
5 \\
5\end{array}$ & $\begin{array}{l}2 \\
5\end{array}$ & \begin{tabular}{|l}
2 \\
4 \\
4
\end{tabular} & $\begin{array}{l}2 \\
. \\
5\end{array}$ & $\begin{array}{l}2 \\
3\end{array}$ & $\begin{array}{l}2 \\
6 \\
6\end{array}$ \\
\hline $\mathrm{C}_{2}$ & $\begin{array}{l}3 \\
4 \\
4\end{array}$ & $\begin{array}{l}0 \\
. \\
0\end{array}$ & $\begin{array}{l}3 \\
3\end{array}$ & $\begin{array}{l}3 \\
0 \\
0\end{array}$ & 0 & $\begin{array}{l}2 \\
. \\
9\end{array}$ & $\begin{array}{l}2 \\
. \\
5\end{array}$ & $\begin{array}{l}2 \\
. \\
5\end{array}$ & $\begin{array}{l}2 \\
. \\
7\end{array}$ & $\begin{array}{l}2 \\
6 \\
6\end{array}$ & $\begin{array}{l}2 \\
8 \\
8\end{array}$ & $\begin{array}{l}2 \\
. \\
7\end{array}$ & $\begin{array}{l}2 \\
. \\
7\end{array}$ & $\begin{array}{l}2 \\
7 \\
7\end{array}$ & $\begin{array}{l}2 \\
. \\
7\end{array}$ & $\begin{array}{l}2 \\
. \\
7\end{array}$ & $\begin{array}{l}2 \\
. \\
5\end{array}$ & $\begin{array}{l}2 \\
2 \\
2\end{array}$ & $\begin{array}{l}2 \\
1 \\
1\end{array}$ & $\begin{array}{l}2 \\
\cdot \\
1\end{array}$ & $\begin{array}{l}2 \\
2 \\
2\end{array}$ & $\begin{array}{l}2 \\
0\end{array}$ & $\begin{array}{l}2 \\
. \\
1\end{array}$ & $\begin{array}{l}2 \\
. \\
0\end{array}$ & $\begin{array}{l}1 \\
. \\
8\end{array}$ & $\begin{array}{l}2 \\
. \\
0\end{array}$ \\
\hline $\mathrm{C}_{3}$ & $\begin{array}{l}3 \\
2 \\
2\end{array}$ & $\begin{array}{l}3 \\
4 \\
4\end{array}$ & $\begin{array}{l}0 \\
0\end{array}$ & 4 & 3 & $\begin{array}{l}3 \\
2\end{array}$ & $\begin{array}{l}2 \\
8 \\
8\end{array}$ & $\begin{array}{l}2 \\
. \\
7\end{array}$ & $\dot{9}$ & . & $\begin{array}{l}2 \\
9\end{array}$ & $\begin{array}{l}2 \\
. \\
9\end{array}$ & $\begin{array}{l}2 \\
7 \\
7\end{array}$ & 7 & $\begin{array}{l}2 \\
6 \\
6\end{array}$ & $\begin{array}{l}2 \\
. \\
5\end{array}$ & $\begin{array}{l}2 \\
8 \\
8\end{array}$ & $\begin{array}{l}2 \\
6 \\
6\end{array}$ & $\begin{array}{l}2 \\
4 \\
4\end{array}$ & $\begin{array}{l}2 \\
4 \\
4\end{array}$ & $\begin{array}{l}2 \\
4 \\
4\end{array}$ & $\dot{1}$ & $\begin{array}{l}2 \\
. \\
0\end{array}$ & $\begin{array}{l}2 \\
. \\
1\end{array}$ & $\begin{array}{l}1 \\
. \\
9\end{array}$ & 1 \\
\hline $\mathrm{C}_{4}$ & $\begin{array}{l}3 \\
3\end{array}$ & $\begin{array}{l}3 \\
2 \\
2\end{array}$ & $\begin{array}{l}3 \\
4\end{array}$ & 0 & 3 & $\begin{array}{l}3 \\
5\end{array}$ & $\begin{array}{l}3 \\
3\end{array}$ & $\begin{array}{l}3 \\
3\end{array}$ & 2 & 3 & $\begin{array}{l}3 \\
3\end{array}$ & $\begin{array}{l}2 \\
. \\
9\end{array}$ & 9 & $\begin{array}{l}2 \\
. \\
9\end{array}$ & $\begin{array}{l}2 \\
7 \\
7\end{array}$ & $\begin{array}{l}2 \\
. \\
7\end{array}$ & $\begin{array}{l}2 \\
. \\
7\end{array}$ & $\begin{array}{l}2 \\
4 \\
4\end{array}$ & 4 & $\begin{array}{l}2 \\
3\end{array}$ & $\begin{array}{l}2 \\
2 \\
2\end{array}$ & 0 & $\begin{array}{l}2 \\
. \\
0\end{array}$ & $\begin{array}{l}2 \\
. \\
0\end{array}$ & $\begin{array}{l}1 \\
9\end{array}$ & 1 \\
\hline $\mathrm{C}_{5}$ & $\begin{array}{l}3 \\
0 \\
0\end{array}$ & $\begin{array}{l}3 \\
2\end{array}$ & $\begin{array}{l}3 \\
3\end{array}$ & $\begin{array}{l}3 \\
5\end{array}$ & 0 & $\begin{array}{l}3 \\
2\end{array}$ & $\begin{array}{l}2 \\
. \\
7\end{array}$ & $\begin{array}{l}2 \\
. \\
7\end{array}$ & $\begin{array}{l}2 \\
. \\
7\end{array}$ & 7 & $\begin{array}{l}2 \\
8\end{array}$ & $\begin{array}{l}2 \\
. \\
5\end{array}$ & $\begin{array}{l}2 \\
7 \\
7\end{array}$ & 6 & $\begin{array}{l}2 \\
4 \\
4\end{array}$ & $\begin{array}{l}2 \\
. \\
4\end{array}$ & $\begin{array}{l}2 \\
. \\
5\end{array}$ & $\begin{array}{l}2 \\
2\end{array}$ & $\begin{array}{l}2 \\
. \\
1\end{array}$ & $\begin{array}{l}2 \\
1 \\
1\end{array}$ & $\begin{array}{l}2 \\
1\end{array}$ & $\dot{0}$ & $\begin{array}{l}2 \\
0\end{array}$ & $\begin{array}{l}1 \\
8\end{array}$ & $\begin{array}{l}1 \\
7 \\
7\end{array}$ & $\begin{array}{l}1 \\
8\end{array}$ \\
\hline $\mathrm{C}_{6}$ & $\begin{array}{l}3 \\
1 \\
1\end{array}$ & $\begin{array}{l}3 \\
1\end{array}$ & $\begin{array}{l}3 \\
2\end{array}$ & $\begin{array}{l}3 \\
5\end{array}$ & 3 & $\begin{array}{l}0 \\
0\end{array}$ & $\begin{array}{l}3 \\
2 \\
2\end{array}$ & $\begin{array}{l}3 \\
. \\
0\end{array}$ & $\begin{array}{l}3 \\
1\end{array}$ & $\begin{array}{l}3 \\
0\end{array}$ & $\begin{array}{l}3 \\
2\end{array}$ & $\begin{array}{l}2 \\
6 \\
6\end{array}$ & $\begin{array}{l}2 \\
. \\
7\end{array}$ & $\begin{array}{l}2 \\
7\end{array}$ & $\begin{array}{l}2 \\
5\end{array}$ & $\begin{array}{l}2 \\
. \\
4\end{array}$ & $\begin{array}{l}2 \\
7\end{array}$ & $\begin{array}{l}2 \\
4\end{array}$ & $\begin{array}{l}2 \\
4 \\
4\end{array}$ & $\begin{array}{l}2 \\
3\end{array}$ & $\begin{array}{l}2 \\
2\end{array}$ & $\begin{array}{l}2 \\
1\end{array}$ & $\begin{array}{l}2 \\
2\end{array}$ & $\begin{array}{l}2 \\
1\end{array}$ & $\begin{array}{l}1 \\
9 \\
9\end{array}$ & $\begin{array}{l}2 \\
1\end{array}$ \\
\hline$C_{7}$ & $\begin{array}{l}2 \\
9\end{array}$ & $\begin{array}{l}2 \\
8 \\
8\end{array}$ & $\begin{array}{l}2 \\
8\end{array}$ & $\begin{array}{l}3 \\
3\end{array}$ & 2 & $\begin{array}{l}3 \\
2\end{array}$ & $\begin{array}{l}0 \\
. \\
0\end{array}$ & $\begin{array}{l}3 \\
1\end{array}$ & $\begin{array}{l}3 \\
1 \\
1\end{array}$ & $\begin{array}{l}3 \\
1 \\
1\end{array}$ & $\begin{array}{l}3 \\
0\end{array}$ & $\begin{array}{l}2 \\
. \\
8\end{array}$ & $\begin{array}{l}3 \\
1 \\
1\end{array}$ & $\begin{array}{l}3 \\
0 \\
0\end{array}$ & $\begin{array}{l}2 \\
. \\
7\end{array}$ & $\begin{array}{l}2 \\
. \\
7\end{array}$ & $\begin{array}{l}3 \\
1\end{array}$ & $\begin{array}{l}2 \\
8\end{array}$ & $\begin{array}{l}3 \\
. \\
0\end{array}$ & $\begin{array}{l}2 \\
9\end{array}$ & $\begin{array}{l}2 \\
8\end{array}$ & $\begin{array}{l}2 \\
6\end{array}$ & $\begin{array}{l}2 \\
4\end{array}$ & $\begin{array}{l}2 \\
3\end{array}$ & $\begin{array}{l}2 \\
4\end{array}$ & $\begin{array}{l}2 \\
7\end{array}$ \\
\hline $\mathrm{C}_{8}$ & $\begin{array}{l}3 \\
0\end{array}$ & $\begin{array}{l}2 \\
8 \\
8\end{array}$ & $\begin{array}{l}2 \\
7\end{array}$ & $\begin{array}{l}3 \\
3\end{array}$ & 2 & $\begin{array}{l}3 \\
0\end{array}$ & $\begin{array}{l}3 \\
1 \\
1\end{array}$ & $\begin{array}{l}0 \\
. \\
0\end{array}$ & $\begin{array}{l}3 \\
2 \\
2\end{array}$ & $\begin{array}{l}3 \\
3 \\
3\end{array}$ & $\begin{array}{l}3 \\
1 \\
1\end{array}$ & $\begin{array}{l}2 \\
. \\
8\end{array}$ & $\begin{array}{l}2 \\
7 \\
7\end{array}$ & $\begin{array}{l}2 \\
8\end{array}$ & $\begin{array}{l}2 \\
8 \\
8\end{array}$ & $\begin{array}{l}2 \\
8 \\
8\end{array}$ & $\begin{array}{l}2 \\
6\end{array}$ & $\begin{array}{l}2 \\
5\end{array}$ & $\begin{array}{l}2 \\
5 \\
5\end{array}$ & $\begin{array}{l}2 \\
4\end{array}$ & $\begin{array}{l}2 \\
3\end{array}$ & $\begin{array}{l}2 \\
7\end{array}$ & $\begin{array}{l}2 \\
5\end{array}$ & $\begin{array}{l}2 \\
6\end{array}$ & $\begin{array}{l}2 \\
4\end{array}$ & $\begin{array}{l}2 \\
5 \\
5\end{array}$ \\
\hline $\mathrm{C}_{9}$ & $\begin{array}{l}2 \\
9\end{array}$ & $\begin{array}{l}3 \\
0 \\
0\end{array}$ & $\begin{array}{l}2 \\
9\end{array}$ & $\begin{array}{l}3 \\
2\end{array}$ & 2 & $\begin{array}{l}3 \\
1\end{array}$ & $\begin{array}{l}3 \\
1 \\
1\end{array}$ & $\begin{array}{l}3 \\
2 \\
2\end{array}$ & . & 3 & $\begin{array}{l}3 \\
2\end{array}$ & $\begin{array}{l}3 \\
. \\
1\end{array}$ & $\begin{array}{l}3 \\
5 \\
5\end{array}$ & 5 & $\begin{array}{l}2 \\
. \\
9\end{array}$ & $\begin{array}{l}3 \\
. \\
1\end{array}$ & $\begin{array}{l}3 \\
2 \\
2\end{array}$ & 7 & $\begin{array}{l}2 \\
5 \\
5\end{array}$ & $\begin{array}{l}2 \\
7\end{array}$ & $\begin{array}{l}2 \\
3\end{array}$ & 4 & $\begin{array}{l}2 \\
4\end{array}$ & $\begin{array}{l}2 \\
5\end{array}$ & $\begin{array}{l}2 \\
3\end{array}$ & $\begin{array}{l}2 \\
3\end{array}$ \\
\hline $\begin{array}{c}\mathrm{C}_{1} \\
0\end{array}$ & $\begin{array}{l}3 \\
1 \\
1\end{array}$ & $\begin{array}{l}2 \\
9 \\
9\end{array}$ & 2 & 3 & 2 & 3 & $\dot{1}$ & 3 & 3 & 0 & 3 & 1 & 3 & 3 & 3 & 0 & 3 & 3 & 9 & 9 & 8 & 2 & 4 & 3 & $\begin{array}{l}2 \\
3\end{array}$ & 2 \\
\hline $\begin{array}{c}\mathrm{C}_{1} \\
1\end{array}$ & $\dot{9}$ & $\dot{0}$ & $\dot{9}$ & 3 & 8 & 3 & 0 & 1 & 2 & 4 & 0 & 0 & 9 & 3 & 0 & 8 & 9 & 7 & $\dot{6}$ & 6 & $\dot{5}$ & 6 & 6 & 7 & 2 & 4 \\
\hline $\begin{array}{c}\mathrm{C}_{1} \\
2\end{array}$ & 4 & 7 & j. & 0 & 6 & $\dot{6}$ & 8 & 8 & 1 & 1 & j & o & 6 & 7 & $\dot{5}$ & $\begin{array}{l}3 \\
4 \\
4\end{array}$ & $\begin{array}{l}3 \\
4\end{array}$ & $\dot{0}$ & $\dot{0}$ & $\begin{array}{l}2 \\
9\end{array}$ & $\begin{array}{l}2 \\
7\end{array}$ & $\dot{6}$ & 4 & $\begin{array}{l}2 \\
5\end{array}$ & $\begin{array}{l}2 \\
2\end{array}$ & 3 \\
\hline $\begin{array}{c}\mathrm{C}_{1} \\
3\end{array}$ & 4 & 8 & $\dot{9}$ & 0 & 2 & 7 & $\dot{1}$ & 7 & 5 & 2 & 9 & 6 & 0 & 3 & 4 & 2 & 3 & 3 & 9 & 8 & 2 & 6 & 5 & $\dot{7}$ & 2 & 2 \\
\hline
\end{tabular}




\begin{tabular}{|c|c|c|c|c|c|c|c|c|c|c|c|c|c|c|c|c|c|c|c|c|c|c|c|c|c|c|}
\hline $\begin{array}{c}\mathrm{Cr} \\
\text { ite } \\
\text { ri } \\
\mathrm{a}_{\mathrm{iij}}\end{array}$ & $\begin{array}{l}\mathrm{C} \\
1\end{array}$ & $\begin{array}{l}\mathrm{C} \\
2\end{array}$ & $\begin{array}{l}\mathrm{C} \\
3\end{array}$ & $\begin{array}{l}\text { C } \\
4\end{array}$ & $\begin{array}{l}\mathrm{C} \\
5\end{array}$ & $\begin{array}{l}C \\
6\end{array}$ & $\begin{array}{l}\text { C } \\
7\end{array}$ & $\begin{array}{l}\mathrm{C} \\
8\end{array}$ & $\begin{array}{l}\mathrm{C} \\
9\end{array}$ & $\begin{array}{l}\mathrm{C} \\
1 \\
0\end{array}$ & $\begin{array}{l}\mathrm{C} \\
1 \\
1\end{array}$ & $\begin{array}{l}\mathrm{C} \\
1 \\
2\end{array}$ & $\begin{array}{l}1 \\
3\end{array}$ & $\begin{array}{l}\mathrm{C} \\
1 \\
4\end{array}$ & $\begin{array}{l}\mathrm{C} \\
1 \\
5\end{array}$ & $\begin{array}{l}\text { C } \\
1 \\
6\end{array}$ & $\begin{array}{l}\mathrm{C} \\
1 \\
7\end{array}$ & $\begin{array}{l}\mathrm{C} \\
1 \\
8\end{array}$ & $\begin{array}{l}\mathrm{C} \\
1 \\
9\end{array}$ & $\begin{array}{l}\mathrm{C} \\
2 \\
0\end{array}$ & $\begin{array}{l}\mathrm{C} \\
2 \\
1\end{array}$ & $\begin{array}{l}\mathrm{C} \\
2 \\
2\end{array}$ & $\begin{array}{l}\mathrm{C} \\
2 \\
3\end{array}$ & $\begin{array}{l}\mathrm{C} \\
2 \\
4\end{array}$ & $\begin{array}{l}\mathrm{C} \\
2 \\
5\end{array}$ & $\begin{array}{l}\text { C } \\
2 \\
6\end{array}$ \\
\hline \multirow{2}{*}{$\begin{array}{c}\mathrm{C}_{1} \\
4\end{array}$} & 3 & 2 & 2 & 3 & 2 & 2 & 3 & 2 & 3 & 3 & 3 & 3 & 3 & 0 & 3 & 3 & 3 & 2 & 3 & 2 & 2 & 2 & 2 & 2 & 2 & 2 \\
\hline & 5 & 8 & 9 & 0 & 7 & 7 & 0 & 8 & 5 & 3 & 3 & 7 & 7 & 0 & 4 & 1 & 1 & 9 & 0 & 9 & 7 & 3 & 4 & 4 & 1 & 3 \\
\hline \multirow{2}{*}{$\begin{array}{c}\mathrm{C}_{1} \\
5\end{array}$} & 3 & 2 & 2 & 2 & 2 & 2 & 2 & 2 & 2 & 3 & 3 & 3 & 3 & 3 & 0 & 3 & 3 & 3 & 3 & 3 & 3 & 2 & 2 & 2 & 2 & 2 \\
\hline & 3 & 8 & 9 & 9 & 4 & 5 & 7 & 8 & 9 & 2 & 0 & 5 & 4 & 4 & 0 & 2 & 3 & 2 & 1 & 1 & 0 & 6 & 7 & 6 & 3 & 4 \\
\hline \multirow{2}{*}{$\begin{array}{c}\mathrm{C}_{1} \\
6\end{array}$} & 3 & 2 & 2 & 2 & 2 & 2 & 2 & 2 & 3 & 3 & 2 & 3 & 3 & 3 & 3 & 0 & 2 & 2 & 2 & 2 & 2 & 2 & 2 & 2 & 2 & 2 \\
\hline & 3 & 8 & 7 & 8 & 4 & 4 & 7 & 8 & 1 & 0 & 8 & 4 & 2 & 1 & 2 & 0 & 9 & 8 & 7 & 8 & 7 & 6 & 5 & 6 & 3 & 4 \\
\hline \multirow{2}{*}{$\begin{array}{c}\mathrm{C}_{1} \\
7\end{array}$} & 3 & 2 & 2 & 2 & 2 & 2 & 3 & 2 & 3 & 3 & 2 & 3 & 3 & 3 & 3 & 2 & 0 & 3 & 3 & 3 & 2 & 3 & 2 & 2 & 2 & 2 \\
\hline & 2 & 7 & 9 & 7 & 5 & 7 & 1 & 6 & 2 & 3 & 9 & 4 & 3 & 1 & 3 & 9 & 0 & 3 & 0 & 0 & 9 & 0 & 9 & 9 & 6 & 8 \\
\hline \multirow{2}{*}{$\begin{array}{c}\mathrm{C}_{1} \\
8\end{array}$} & 2 & 2 & 2 & 2 & 2 & 2 & 2 & 2 & 2 & 3 & 2 & 3 & 3 & 2 & 3 & 2 & 3 & 0 & 3 & 3 & 3 & 2 & 2 & 2 & 2 & 2 \\
\hline & 9 & 5 & 7 & 4 & 2 & 4 & 8 & 5 & 7 & 1 & 7 & 0 & 1 & 9 & 2 & 8 & 3 & 0 & 2 & 2 & 1 & 9 & 9 & 8 & 8 & 8 \\
\hline \multirow{2}{*}{$\begin{array}{c}\mathrm{C}_{1} \\
9\end{array}$} & 2 & 2 & 2 & 2 & 2 & 2 & 3 & 2 & 2 & 2 & 2 & 3 & 2 & 3 & 3 & 2 & 3 & 3 & 0 & 3 & 3 & 3 & 2 & 2 & 2 & 3 \\
\hline & 5 & 3 & 5 & 4 & 1 & 4 & 0 & 5 & 5 & 9 & 6 & 0 & 9 & 0 & 1 & 7 & 0 & 2 & 0 & 1 & 1 & 0 & 8 & 6 & 8 & 2 \\
\hline \multirow{2}{*}{$\begin{array}{c}\mathrm{C}_{2} \\
0\end{array}$} & 2 & 2 & 2 & 2 & 2 & 2 & 2 & 2 & 2 & 2 & 2 & 2 & 2 & 2 & 3 & 2 & 3 & 3 & 3 & 0 & 2 & 3 & 3 & 3 & 2 & 3 \\
\hline & 5 & 3 & 5 & 3 & 1 & 3 & 9 & 4 & 7 & 9 & 6 & 9 & 8 & 9 & 1 & 8 & 0 & 2 & 1 & 0 & 9 & 2 & 1 & 1 & 8 & 1 \\
\hline \multirow{2}{*}{$\begin{array}{c}\mathrm{C}_{2} \\
1\end{array}$} & 2 & 2 & 2 & 2 & 2 & 2 & 2 & 2 & 2 & 2 & 2 & 2 & 2 & ? & 3 & 2 & 2 & 3 & 3 & 2 & 0 & 2 & 2 & 2 & 2 & 2 \\
\hline & 7 & 4 & 5 & 2 & 1 & 2 & 8 & 3 & 3 & 8 & 5 & 7 & 7 & 7 & 0 & 7 & 9 & 1 & 1 & 9 & 0 & 5 & 4 & 4 & 1 & 4 \\
\hline \multirow{2}{*}{$\begin{array}{c}\mathrm{C}_{2} \\
2\end{array}$} & 2 & 2 & 2 & 2 & 2 & 2 & 2 & 2 & 2 & 2 & 2 & 2 & 2 & 2 & 2 & 2 & 3 & 2 & 3 & 3 & 2 & 0 & 2 & 2 & 2 & 3 \\
\hline & 7 & 2 & 1 & 1 & 0 & 1 & 6 & 7 & 4 & 7 & 6 & 6 & 6 & 3 & 6 & 6 & 0 & 9 & 0 & 2 & 5 & 0 & 7 & 5 & 4 & 0 \\
\hline \multirow{2}{*}{$\begin{array}{c}\mathrm{C}_{2} \\
3\end{array}$} & 2 & 2 & 2 & 2 & 2 & 2 & 2 & 2 & 2 & 2 & 2 & 2 & 2 & 2 & 2 & 2 & 2 & 2 & 2 & 3 & 2 & 2 & 0 & 3 & 2 & 3 \\
\hline & 6 & 2 & 0 & 0 & 0 & 2 & 4 & 5 & 4 & 4 & 6 & 4 & 5 & 4 & 7 & 5 & 9 & 9 & 8 & 1 & 4 & 7 & 0 & 0 & 3 & 1 \\
\hline \multirow{2}{*}{$\begin{array}{c}\mathrm{C}_{2} \\
4\end{array}$} & 2 & 2 & 2 & 2 & 1 & 2 & 2 & 2 & 2 & 2 & 2 & 2 & 2 & 2 & 2 & 2 & 2 & 2 & 2 & 3 & 2 & 2 & 3 & 0 & 2 & 3 \\
\hline & 7 & 2 & 1 & 1 & 8 & 1 & 3 & 6 & 5 & 3 & 7 & 5 & 7 & 4 & 6 & 6 & 9 & 8 & 6 & 1 & 4 & 5 & 0 & 0 & 4 & 3 \\
\hline \multirow{2}{*}{$\begin{array}{c}\mathrm{C}_{2} \\
5\end{array}$} & 2 & 2 & 1 & 1 & 1 & 1 & 2 & 2 & 2 & 2 & 2 & 2 & 2 & 2 & 2 & 2 & 2 & 2 & 2 & 2 & 2 & 2 & 2 & 2 & 0 & 3 \\
\hline & 5 & 0 & 9 & 9 & 7 & 9 & 4 & 4 & 3 & 3 & 2 & 2 & 3 & 1 & 3 & 3 & 6 & 8 & 8 & 8 & 1 & 4 & 3 & 4 & 0 & 0 \\
\hline \multirow{2}{*}{$\begin{array}{c}\mathrm{C}_{2} \\
6\end{array}$} & 2 & 2 & 1 & 2 & 1 & 2 & 2 & 2 & 2 & 2 & 2 & 2 & 2 & 2 & 2 & 2 & 2 & 2 & 3 & 3 & 2 & 3 & 3 & 3 & 3 & 0 \\
\hline & 8 & 2 & 8 & 0 & 8 & 1 & 7 & 5 & 3 & 5 & 4 & 3 & 4 & 3 & 4 & 4 & 8 & 8 & 2 & 1 & 4 & 0 & 1 & 3 & 2 & 0 \\
\hline
\end{tabular}


The model for measuring the Quality of Sustainability Reporting...

Table 19. Results of Fuzzy DEMATEL Technique

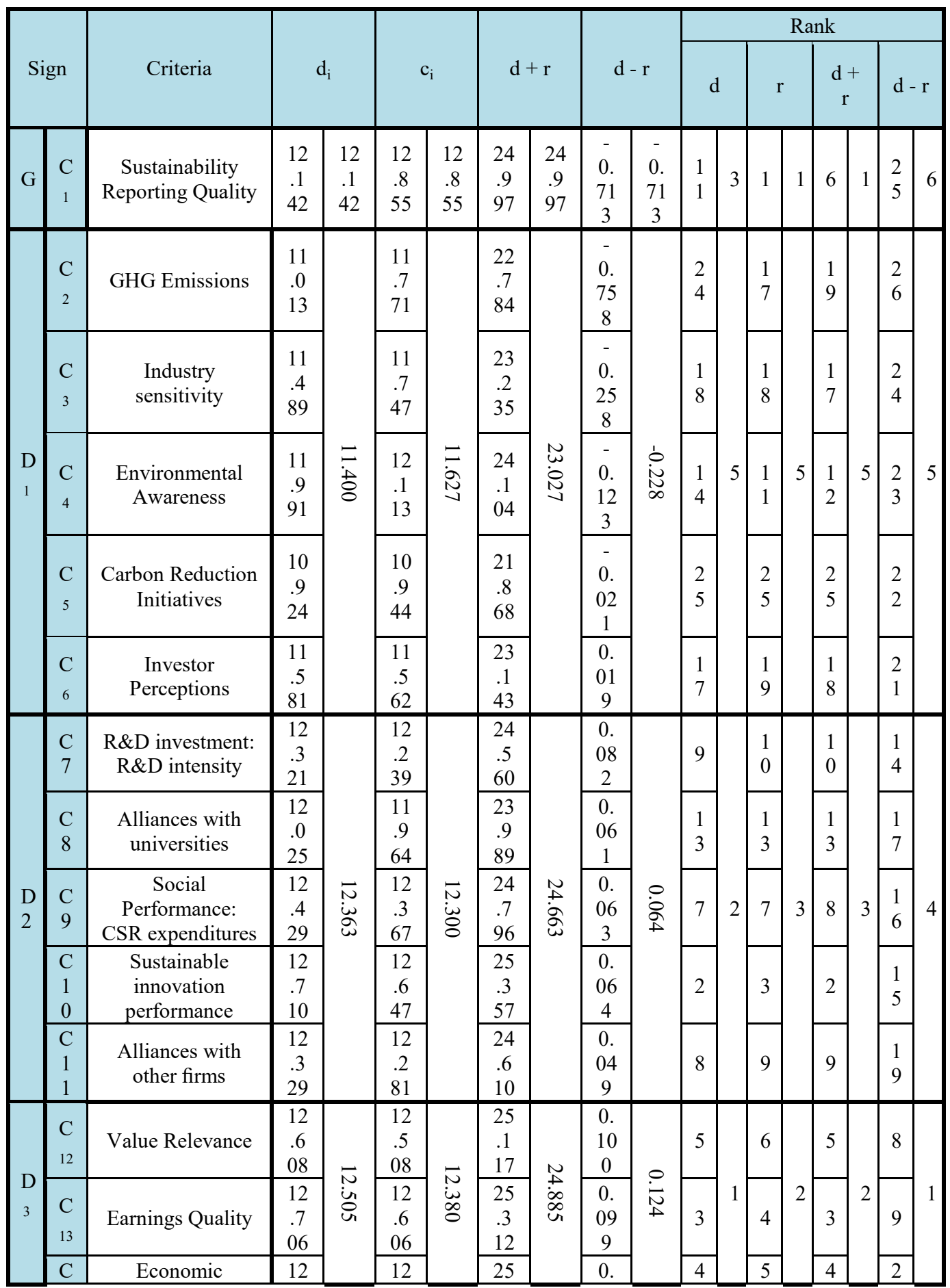




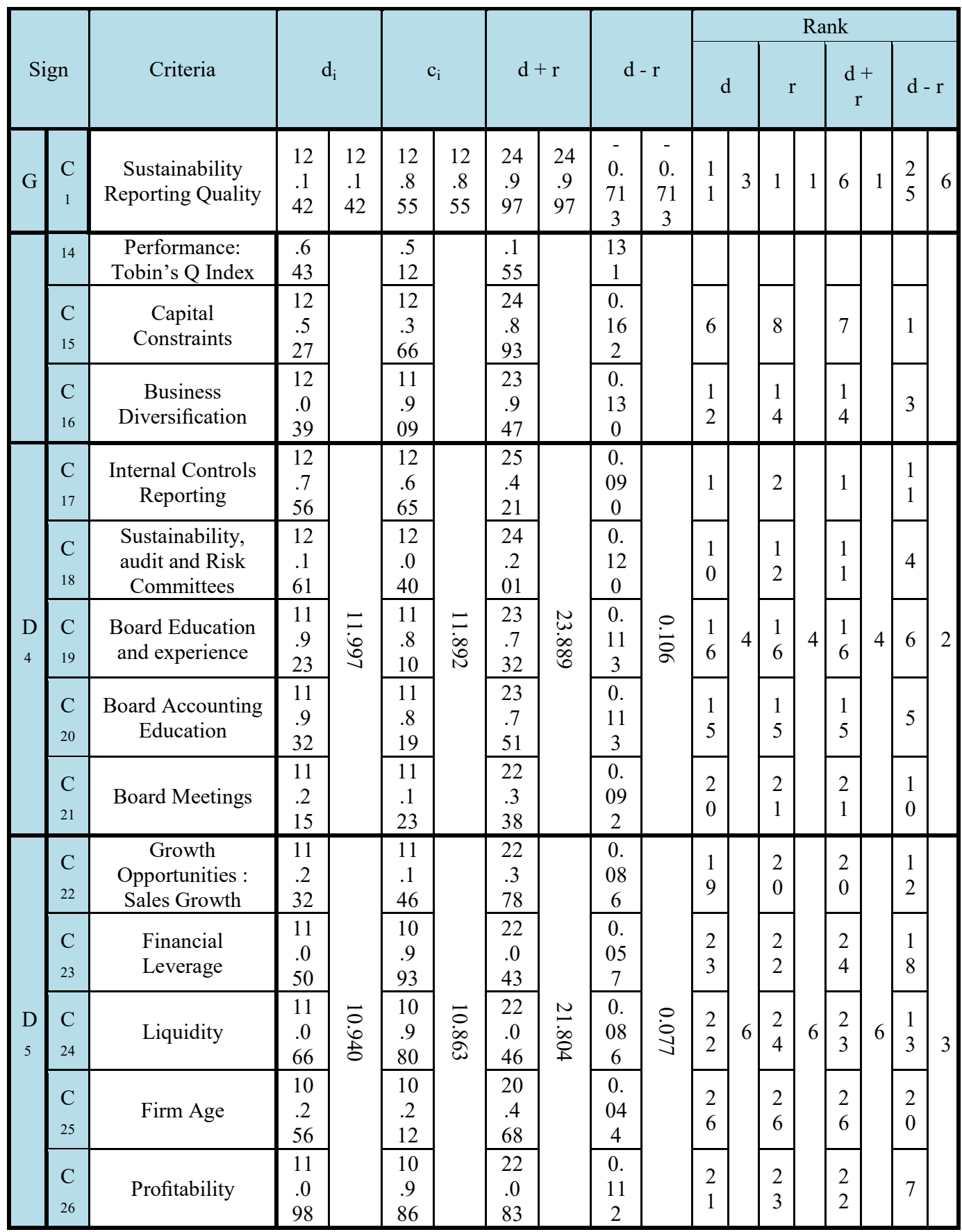


The model for measuring the Quality of Sustainability Reporting...

Table 20. Results of ranking effective dimensions in the quality of sustainability reporting based on fuzzy DANP technique

\begin{tabular}{|c|c|c|c|}
\hline Sign & Dimensions & Weight & Rank \\
\hline $\mathrm{D}_{2}$ & Social & 0.04018 & 1 \\
\hline $\mathrm{D}_{3}$ & Economic & 0.03991 & 2 \\
\hline $\mathrm{D}_{4}$ & Corporate Governance & 0.03859 & 3 \\
\hline $\mathrm{D}_{1}$ & Environmental & 0.03773 & 4 \\
\hline $\mathrm{D}_{5}$ & Corporate Characteristics & 0.03525 & 5 \\
\hline
\end{tabular}

Table 21. Results of ranking the effective criteria in the quality of sustainability reporting based on fuzzy DANP technique

\begin{tabular}{|c|c|c|c|}
\hline Sign & Criteria & Weight & Rank \\
\hline $\mathrm{C}_{17}$ & Internal Controls Reporting & 0.04110 & 1 \\
\hline $\mathrm{C}_{10}$ & Sustainable innovation performance: patent & 0.04104 & 2 \\
\hline $\mathrm{C}_{13}$ & Earnings Quality & 0.04091 & 3 \\
\hline $\mathrm{C}_{14}$ & Firms' Economic Performance: Tobin's Q Index & 0.04060 & 4 \\
\hline $\mathrm{C}_{12}$ & Value Relevance & 0.04059 & 5 \\
\hline $\mathrm{C}_{9}$ & Social Performance: CSR expenditures & 0.04013 & 6 \\
\hline $\mathrm{C}_{15}$ & Capital Constraints & 0.04013 & 7 \\
\hline $\mathrm{C}_{11}$ & Alliances with other firms & 0.03985 & 8 \\
\hline $\mathrm{C}_{7}$ & R\&D investment: R\&D intensity & 0.03972 & 9 \\
\hline $\mathrm{C}_{4}$ & Environmental Awareness & 0.03931 & 10 \\
\hline $\mathrm{C}_{18}$ & Sustainability, audit and Risk Committees & 0.03907 & 11 \\
\hline $\mathrm{C}_{8}$ & Alliances with universities & 0.03883 & 12 \\
\hline $\mathrm{C}_{16}$ & Business Diversification & 0.03865 & 13 \\
\hline $\mathrm{C}_{20}$ & Board Education and experience & 0.03835 & 14 \\
\hline $\mathrm{C}_{19}$ & Board Education and experience & 0.03832 & 15 \\
\hline $\mathrm{C}_{2}$ & GHG Emissions & 0.03819 & 16 \\
\hline $\mathrm{C}_{3}$ & Industry sensitivity & 0.03812 & 17 \\
\hline $\mathrm{C}_{6}$ & Investor Perceptions & 0.03752 & 18 \\
\hline $\mathrm{C}_{22}$ & Growth Opportunities :Sales Growth & 0.03617 & 19 \\
\hline $\mathrm{C}_{21}$ & Board Meetings & 0.03609 & 20 \\
\hline $\mathrm{C}_{23}$ & Financial Leverage & 0.03567 & 21 \\
\hline $\mathrm{C}_{26}$ & Profitability & 0.03565 & 22 \\
\hline $\mathrm{C}_{24}$ & Liquidity & 0.03563 & 23 \\
\hline $\mathrm{C}_{5}$ & Firm Age & 0.03552 & 24 \\
\hline $\mathrm{C}_{25}$ & & 0.03314 & 25 \\
\hline & & & \\
\hline
\end{tabular}


Iranian Journal of Finance, 2022, Vol. 6, No. 2 (Esmaeilzadeh, H.)

Table 22. Matrix of internal relations between the effective factors based on the threshold value (average) of the total matrix (T), value one means the existence of a relationship and value zero means no relationship

\begin{tabular}{|c|c|c|c|c|c|c|c|c|c|c|c|c|c|c|c|c|c|c|c|c|c|c|c|c|c|c|}
\hline $\begin{array}{c}\mathrm{Cr} \\
\text { ite } \\
\text { ri } \\
\mathrm{a} \\
\end{array}$ & $\begin{array}{l}\mathrm{C} \\
1\end{array}$ & $\begin{array}{l}C \\
2\end{array}$ & $\begin{array}{l}C \\
3\end{array}$ & $\begin{array}{l}\mathrm{C} \\
4\end{array}$ & $\begin{array}{l}\mathrm{C} \\
5\end{array}$ & $\begin{array}{l}\mathrm{C} \\
6\end{array}$ & $\begin{array}{l}\mathrm{C} \\
7\end{array}$ & \begin{tabular}{|c}
$\mathrm{C}$ \\
8
\end{tabular} & $\begin{array}{l}\mathrm{C} \\
9\end{array}$ & \begin{tabular}{|l}
$\mathrm{C}$ \\
1 \\
0
\end{tabular} & & $\begin{array}{l}\mathrm{C} \\
1 \\
2\end{array}$ & \begin{tabular}{|l}
$\mathrm{C}$ \\
1 \\
3
\end{tabular} & $\begin{array}{l}\mathrm{C} \\
1 \\
4\end{array}$ & $\begin{array}{l}\mathrm{C} \\
1 \\
5\end{array}$ & \begin{tabular}{|l}
$\mathrm{C}$ \\
1 \\
6
\end{tabular} & $\begin{array}{l}\mathrm{C} \\
1 \\
7\end{array}$ & $\begin{array}{l}\mathrm{C} \\
1 \\
8\end{array}$ & $\begin{array}{l}\mathrm{C} \\
1 \\
9\end{array}$ & $\mid \begin{array}{l}\mathrm{C} \\
2 \\
0\end{array}$ & $\begin{array}{l}\mathrm{C} \\
2 \\
1\end{array}$ & \begin{tabular}{|l}
$\mathrm{C}$ \\
2 \\
2
\end{tabular} & $\begin{array}{l}\mathrm{C} \\
2 \\
3\end{array}$ & $\begin{array}{l}\mathrm{C} \\
2 \\
4\end{array}$ & $\begin{array}{l}\mathrm{C} \\
2 \\
5\end{array}$ & $\begin{array}{l}\mathrm{C} \\
2 \\
6\end{array}$ \\
\hline C & 1 & 1 & 1 & 1 & 0 & 1 & 1 & 1 & 1 & 1 & 1 & 1 & 1 & 1 & 1 & 1 & 1 & 1 & 1 & 1 & 0 & 0 & 0 & 0 & 0 & 0 \\
\hline C & 1 & 0 & 0 & 0 & 0 & 0 & 0 & 0 & 0 & 0 & 0 & 0 & 0 & 0 & 0 & 0 & 0 & 0 & 0 & 0 & 0 & 0 & 0 & 0 & 0 & 0 \\
\hline $\begin{array}{l}\mathrm{C} \\
3 \\
\end{array}$ & 1 & 0 & 0 & 1 & 0 & 0 & 1 & 0 & 1 & 1 & 1 & 1 & 1 & 1 & 1 & 0 & 1 & 0 & 0 & 0 & 0 & 0 & 0 & 0 & 0 & 0 \\
\hline $\begin{array}{l}\mathrm{C} \\
4 \\
\end{array}$ & 1 & 1 & 1 & 0 & 0 & 1 & 1 & 1 & 1 & 1 & 1 & 1 & 1 & 1 & 1 & 1 & 1 & 1 & 0 & 0 & 0 & 0 & 0 & 0 & 0 & 0 \\
\hline $\begin{array}{l}\mathrm{C} \\
5\end{array}$ & 1 & 0 & 0 & 0 & 0 & 0 & 0 & 0 & 0 & 0 & 0 & 0 & 0 & 0 & 0 & 0 & 0 & 0 & 0 & 0 & 0 & 0 & 0 & 0 & 0 & 0 \\
\hline $\begin{array}{l}\mathrm{C} \\
6 \\
\end{array}$ & 1 & 0 & 0 & 1 & 0 & 0 & 1 & 0 & 1 & 1 & 1 & 1 & 1 & 1 & 1 & 0 & 1 & 0 & 0 & 0 & 0 & 0 & 0 & 0 & 0 & 0 \\
\hline $\begin{array}{l}\mathrm{C} \\
7 \\
\end{array}$ & 1 & 1 & 1 & 1 & 0 & 1 & 1 & 1 & 1 & 1 & 1 & 1 & 1 & 1 & 1 & 1 & 1 & 1 & 1 & 1 & 0 & 0 & 0 & 0 & 0 & 0 \\
\hline $\begin{array}{l}\mathrm{C} \\
8\end{array}$ & 1 & 1 & 1 & 1 & 0 & 1 & 1 & 0 & 1 & 1 & 1 & 1 & 1 & 1 & 1 & 1 & 1 & 1 & 1 & 1 & 0 & 0 & 0 & 0 & 0 & 0 \\
\hline $\begin{array}{l}\mathrm{C} \\
9\end{array}$ & 1 & 1 & 1 & 1 & 0 & 1 & 1 & 1 & 1 & 1 & 1 & 1 & 1 & 1 & 1 & 1 & 1 & 1 & 1 & 1 & 0 & 0 & 0 & 0 & 0 & 0 \\
\hline $\begin{array}{l}\mathrm{C} \\
10 \\
\end{array}$ & 1 & 1 & 1 & 1 & 0 & 1 & 1 & 1 & 1 & 1 & 1 & 1 & 1 & 1 & 1 & 1 & 1 & 1 & 1 & 1 & 1 & 1 & 0 & 0 & 0 & 0 \\
\hline $\begin{array}{l}\mathrm{C} \\
11\end{array}$ & 1 & 1 & 1 & 1 & 0 & 1 & 1 & 1 & 1 & 1 & 1 & 1 & 1 & 1 & 1 & 1 & 1 & 1 & 1 & 1 & 0 & 0 & 0 & 0 & 0 & 0 \\
\hline $\begin{array}{l}\mathrm{C} \\
12\end{array}$ & 1 & 1 & 1 & 1 & 0 & 1 & 1 & 1 & 1 & 1 & 1 & 1 & 1 & 1 & 1 & 1 & 1 & 1 & 1 & 1 & 1 & 0 & 0 & 0 & 0 & 0 \\
\hline $\begin{array}{l}\mathrm{C} \\
13 \\
\end{array}$ & 1 & 1 & 1 & 1 & 0 & 1 & 1 & 1 & 1 & 1 & 1 & 1 & 1 & 1 & 1 & 1 & 1 & 1 & 1 & 1 & 1 & 1 & 0 & 0 & 0 & 0 \\
\hline $\begin{array}{l}\mathrm{C} \\
14\end{array}$ & 1 & 1 & 1 & 1 & 0 & 1 & 1 & 1 & 1 & 1 & 1 & 1 & 1 & 1 & 1 & 1 & 1 & 1 & 1 & 1 & 1 & 0 & 0 & 0 & 0 & 0 \\
\hline $\begin{array}{l}\mathrm{C} \\
15 \\
\end{array}$ & 1 & 1 & 1 & 1 & 0 & 1 & 1 & 1 & 1 & 1 & 1 & 1 & 1 & 1 & 1 & 1 & 1 & 1 & 1 & 1 & 1 & 0 & 0 & 0 & 0 & 0 \\
\hline $\begin{array}{l}\mathrm{C} \\
16 \\
\end{array}$ & 1 & 1 & 1 & 1 & 0 & 0 & 1 & 1 & 1 & 1 & 1 & 1 & 1 & 1 & 1 & 0 & 1 & 1 & 1 & 1 & 0 & 0 & 0 & 0 & 0 & 0 \\
\hline $\begin{array}{l}\mathrm{C} \\
17 \\
\end{array}$ & 1 & 1 & 1 & 1 & 0 & 1 & 1 & 1 & 1 & 1 & 1 & 1 & 1 & 1 & 1 & 1 & 1 & 1 & 1 & 1 & 1 & 1 & 1 & 1 & 0 & 1 \\
\hline $\begin{array}{l}\mathrm{C} \\
18 \\
\end{array}$ & 1 & 1 & 1 & 1 & 0 & 0 & 1 & 1 & 1 & 1 & 1 & 1 & 1 & 1 & 1 & 1 & 1 & 0 & 1 & 1 & 0 & 0 & 0 & 0 & 0 & 0 \\
\hline $\begin{array}{l}\mathrm{C} \\
19 \\
\end{array}$ & 1 & 0 & 0 & 1 & 0 & 0 & 1 & 1 & 1 & 1 & 1 & 1 & 1 & 1 & 1 & 1 & 1 & 1 & 0 & 1 & 0 & 0 & 0 & 0 & 0 & 0 \\
\hline $\begin{array}{l}\mathrm{C} \\
20 \\
\end{array}$ & 1 & 0 & 0 & 1 & 0 & 0 & 1 & 1 & 1 & 1 & 1 & 1 & 1 & 1 & 1 & 1 & 1 & 1 & 1 & 0 & 0 & 0 & 0 & 0 & 0 & 0 \\
\hline $\begin{array}{l}\mathrm{C} \\
21 \\
\end{array}$ & 1 & 0 & 0 & 0 & 0 & 0 & 0 & 0 & 0 & 1 & 0 & 1 & 1 & 1 & 0 & 0 & 1 & 0 & 0 & 0 & 0 & 0 & 0 & 0 & 0 & 0 \\
\hline $\mathrm{C}$ & 1 & 0 & 0 & 0 & 0 & 0 & 0 & 0 & 0 & 1 & 0 & 0 & 1 & 0 & 0 & 0 & 1 & 0 & 0 & \begin{tabular}{|l}
0 \\
\end{tabular} & 0 & 0 & 0 & 0 & 0 & 0 \\
\hline
\end{tabular}




\begin{tabular}{|c|c|c|c|c|c|c|c|c|c|c|c|c|c|c|c|c|c|c|c|c|c|c|c|c|c|c|}
\hline $\begin{array}{c}\mathrm{Cr} \\
\text { ite } \\
\text { ri } \\
\mathrm{a}\end{array}$ & $\begin{array}{l}\mathrm{C} \\
1\end{array}$ & $\begin{array}{l}\mathrm{C} \\
2\end{array}$ & $\begin{array}{l}\mathrm{C} \\
3\end{array}$ & $\begin{array}{l}\mathrm{C} \\
4\end{array}$ & $\begin{array}{l}\mathrm{C} \\
5\end{array}$ & $\begin{array}{l}\mathrm{C} \\
6\end{array}$ & $\begin{array}{l}C \\
7\end{array}$ & $\begin{array}{l}\mathrm{C} \\
8\end{array}$ & $\begin{array}{l}\mathrm{C} \\
9\end{array}$ & $\begin{array}{l}\mathrm{C} \\
1 \\
0\end{array}$ & $\begin{array}{l}\mathrm{C} \\
1 \\
1\end{array}$ & $\begin{array}{l}\mathrm{C} \\
1 \\
2\end{array}$ & $\begin{array}{l}\mathrm{C} \\
1 \\
3\end{array}$ & $\begin{array}{l}\mathrm{C} \\
1 \\
4\end{array}$ & $\begin{array}{l}\mathrm{C} \\
1 \\
5\end{array}$ & $\begin{array}{l}\text { C } \\
1 \\
6\end{array}$ & $\begin{array}{l}\mathrm{C} \\
1 \\
7\end{array}$ & $\begin{array}{l}\text { C } \\
1 \\
8\end{array}$ & $\begin{array}{l}\text { C } \\
1 \\
9\end{array}$ & $\begin{array}{l}\mathrm{C} \\
2 \\
0\end{array}$ & $\begin{array}{l}\mathrm{C} \\
2 \\
1\end{array}$ & $\begin{array}{l}\mathrm{C} \\
2 \\
2\end{array}$ & $\begin{array}{l}\mathrm{C} \\
2 \\
3\end{array}$ & $\begin{array}{l}\mathrm{C} \\
2 \\
4\end{array}$ & $\begin{array}{l}\mathrm{C} \\
2 \\
5\end{array}$ & $\begin{array}{l}\mathrm{C} \\
2 \\
6\end{array}$ \\
\hline 22 & & & & & & & & & & & & & & & & & & & & & & & & & & \\
\hline $\begin{array}{l}\mathrm{C} \\
23\end{array}$ & 1 & 0 & 0 & 0 & 0 & 0 & 0 & 0 & 0 & 0 & 0 & 0 & 0 & 0 & 0 & 0 & 1 & 0 & 0 & 0 & 0 & 0 & 0 & 0 & 0 & 0 \\
\hline $\begin{array}{l}\mathrm{C} \\
24\end{array}$ & 1 & 0 & 0 & 0 & 0 & 0 & 0 & 0 & 0 & 0 & 0 & 0 & 0 & 0 & 0 & 0 & 1 & 0 & 0 & 0 & 0 & 0 & 0 & 0 & 0 & 0 \\
\hline C & 0 & 0 & 0 & 0 & 0 & 0 & 0 & 0 & 0 & 0 & 0 & 0 & 0 & 0 & 0 & 0 & 0 & 0 & 0 & 0 & 0 & 0 & 0 & 0 & 0 & 0 \\
\hline $\mathrm{C}$ & 1 & 0 & 0 & 0 & 0 & 0 & 0 & 0 & 0 & 0 & 0 & 0 & 0 & 0 & 0 & 0 & 1 & 0 & 0 & 0 & 0 & 0 & 0 & 0 & 0 & 0 \\
\hline
\end{tabular}

\section{Conclusion}

The GRI's reporting Principles for Sustainability Reporting Checklist rated top among experts in assessing the quality of sustainability reporting, according to pairwise comparisons based on the FAHP methodology. In answer to the research question, whether the provided information is accurate and detailed, represents the good and negative aspects of the organization's performance, and is prepared and accessible in an understandable manner, according to the GRI's sustainability reporting principles. As a consequence, stakeholders can have a more accurate and rational assessment of the organization's performance. Furthermore, consistency in selection, compilation, and reporting enables stakeholders to examine changes in the organization's performance over time and compare it to the performance of other companies. If the information in the report is a third-party guarantee, and the findings are delivered to stakeholders as soon as possible. In that scenario, their worth and significance will be validated, allowing them to make more educated judgments. Sustainability reporting quality Criteria were extracted from Daub (2007); Amran et al. (2014); Gao et al. (2016); Al-shaer and Zaman (2016); Munshi and Dutta (2016); Krivacic (2017); Ching et al. (2017); Diouf and Bioral (2017); Ho and Loh (2018); Rezaee and Tao (2019); Bakar, Ghazali, and Ahmad (2019); Moses et al. (2020); Garcia et al. (2020); Khan et al. (2020); Badia et al. (2020); Al-shaer, (2020); Adoui (2020); Jadoon et al. (2021) studies. As a result, these criteria may be recommended for further study in Iran to evaluate the quality of sustainability reporting.

According to the FDANP findings, internal controls reporting was identified as one of the variables influencing the quality of sustainability reporting by research experts. Internal control reporting is one of the influencing elements on the components of sustainability reporting, including 
corporate governance, corporate social responsibility, and corporate environment, according to a study performed by Li et al. (2020); Cigdem et al. (2018); Huang and Huang (2020). As a consequence, the findings of the study are consistent with those of the previous studies. Climate change, population expansion, lifestyle changes, and customer needs for new goods all allow companies to explore innovation as a means of achieving long-term success. As a result, one of the decisive variables is the performance of sustainable innovation. The assessment used in this study is based on Jeong and Shin's research in this area (2020). According to previous research, voluntary disclosures, such as sustainability disclosures, can either replace or complement lower-quality profits and required financial reporting. As a result, this research confirms the complimentary connection that high-profit firms publish more disclosures, increasing the trustworthiness and reputation of corporate reporting. Our findings are consistent with those of Rezaee and Tao (2019); Al-shaer (2019; 2020).

The parameters impacting the quality of sustainability reporting, internal controls reporting, sustainable innovation performance, and earnings quality have the highest influence and interaction in the network in internal relations analysis. The factors of sustainability reporting quality, internal controls reporting, and sustainable innovation performance, on the other side, have had the greatest influence. Capital restriction, economic performance, and business variety were also found as causative factors. On the other side, as effect factors, the variables of industry sensitivity, sustainability reporting quality, and decrease of greenhouse gas emissions are included. Experts recognize the significance of internal controls reporting, sustainable innovation performance, and earnings quality characteristics, and have identified them as the most significant criteria in assessing the quality of sustainable reporting. Furthermore, they raised to worry about liquidity, carbon reduction initiative factors, and the firm's age, all of which they deemed irrelevant in the value.

These criteria were extracted from Iatridis (2013); Harris (2014); Munshi and Dutta (2016); Diouf and Bioral (2017), Haque (2017); khosroshahi and vatankhah (2017); Alfarooque and Ahulu (2017); Locar et al. (2019); Rezaee and Tao (2019); Wasara and Ganda (2019); Orazalin and Mahmood (2018); Nilipour et al. (2020); Moses et al. (2020); Hill, (2020); Jeong and Shin (2020); Khan et al. (2020); Huang and Huang, (2020); Al-Shaer, (2020); Nguyen, (2020); Khan, R, et al., (2020); Giron et al. (2020); Ruhana and Hidayah, (2020); Vitolla et al. (2020); Ahmadyan and ghasemi (2021); Hamidi, (2021) studies. 
The model for measuring the Quality of Sustainability Reporting...

As a result of the research findings, policymakers are encouraged to create standards for audited internal control reports to be prepared and published with other annual reports. The measure of sustainable innovation performance is another element impacting the quality of sustainability reporting. To attain this level of success, firms must collaborate more closely with colleges and other companies. Invest in research and development to create knowledge-based and creative value chain processes. As a result, they will gain a competitive edge and be free of capital limitations. Because the current study is a database (rather than a database), one of its drawbacks is the difficult access to specialists, particularly recognized faculty members of institutions who are frequently involved in administrative issues.

Other important factors, such as technological advancements, financial and legal changes, should be included in future research. In the business community, financial technology, often known as fintech, refers to companies that use technology to improve the efficiency of financial services. Another innovative application of technology is regulatory technology, which allows for efficient and low-cost legislation and regulatory compliance. Furthermore, in the future study, they may use real data to demonstrate the network's underlying interconnections using a quantitative method.

\section{Declaration of Conflicting Interests}

The authors declared no potential conflicts of interest concerning the research, authorship and, or publication of this article.

\section{Funding}

The authors received no financial support for the research, authorship and, or publication of this article. 


\section{References}

Abdi, M., Kordestani, G., Rezazadeh, J. (2020). Sustainability Reporting: Ratings of Drivers and Indicators. Empirical Research in Accounting, 10(2), 71-114. doi: 10.22051/jera.2019.25698.2404

Abdi, Y., Li, X., \& Càmara-Turull, X. (2020). Impact of Sustainability on Firm Value and Financial Performance in the Air Transport Industry. Sustainability, 12(23), 9957.

Acs, Z. J., Anselin, L., \& Varga, A. (2002). Patents and innovation count as measures of regional production of new knowledge. Research Policy, 31(7), 1069-1085.

Adams, S., \& Simnett, R. (2011). Integrated reporting: An opportunity for Australia's not-for-profit sector. Australian Accounting Review, 21(3), 292-301. https://doi.org/10.1111/j.1835-2561 .2011.00143.x

Adaui, C. R. L. (2020). Sustainability reporting quality of Peruvian listed companies and the impact of regulatory requirements of sustainability disclosures. Sustainability, 12(3), 1135.

Ahmadyan, A., Ghasemi Ali Abadi, M. (2021). Corporate Governance and Iranian Banking Economic Value Added. Iranian Journal of Finance, 5(2), 46-69. doi: 10.30699/ijf.2021.211225.1096

Alipour, M., Ghanbari, M., Jamshidinavid, B., \& Taherabadi, A. (2019). The relationship between environmental disclosure quality and earnings quality: a panel study of an emerging market. Journal of Asia Business Studies, 13(2), 326-347.

Al-Shaer, H. (2020). Sustainability reporting quality and post-audit financial reporting quality: Empirical evidence from the UK. Business Strategy and the Environment, 29(6), 2355-2373.

Al-Shaer, H., \& Zaman, M. (2016). Board gender diversity and sustainability reporting quality. Journal of Contemporary Accounting and Economics, $12(3), 210-222$.

Al-Shaer, H., \& Zaman, M. (2018). The credibility of sustainability reports: The contribution of audit committees. Business strategy and the environment, 27(7), 973-986.

Alshehhi, A., Nobanee, H., \& Khare, N. (2018). The impact of sustainability practices on corporate financial performance: Literature trends and future research potential. Sustainability, 10(2), 494. 
The model for measuring the Quality of Sustainability Reporting...

61

Amran, A., Lee, S. P., \& Devi, S. S. (2014). The influence of governance structure and strategic corporate social responsibility toward sustainability reporting quality. Business Strategy and the Environment, 23(4), 217-235.

Aureli, S., Gigli, S., Medei, R., \& Supino, E. (2020). The value relevance of environmental, social, and governance disclosure: Evidence from Dow Jones Sustainability World Index listed companies. Corporate Social Responsibility and Environmental Management, 27(1), 43-52.

Badia, F., Bracci, E., \& Tallaki, M. (2020). Quality and diffusion of social and sustainability reporting in Italian public utility companies. Sustainability, 12(11), 4525.

Bae, S. M., Masud, M., Kaium, A., \& Kim, J. D. (2018). A cross-country investigation of corporate governance and corporate sustainability disclosure: A signaling theory perspective. Sustainability, 10(8), 2611.

Bakar, A. B. S. A., Ghazali, N. A. B. M., \& Ahmad, M. B. (2019). Sustainability reporting and board diversity in Malaysia. International Journal of Academic Research in Business and Social Sciences, 9(3).

Behbahaninia, P. S., \& Golbidi, M. (2020). CEO Power and Sustainability Reporting in Iran: Effect of Life Cycle and International Relations. Iranian Journal of Finance, 4(3), 103-121.

Bos-Brouwers, H. E. J. (2010). Corporate sustainability and innovation in SMEs: evidence of themes and activities in practice. Business strategy and the environment, 19(7), 417-435.

Bose, S., Saha, A., Khan, H. Z., \& Islam, S. (2017). Non-financial disclosure and market-based firm performance: The initiation of financial inclusion. Journal of Contemporary Accounting and Economics, 13(3), 263-281. https://doi.org/10.1016/j. jcae.2017.09.006

Briem, C. R., \& Wald, A. (2018). Implementing third-party assurance in integrated reporting: Companies' motivation and auditors' role. Accounting, Auditing and Accountability Journal, 31(5), 1461-1485. https://doi.org/10.1108/AAAJ-03-2016-2447

Camilleri, M. A. (2018). Theoretical insights on integrated reporting: The inclusion of non-financial capitals in corporate disclosures. Corporate Communications: An International Journal, 23(4), 567-581. https://doi.org/10.1108/CCIJ-01-2018-0016 
Chauvey, J. N., Giordano-Spring, S., Cho, C. H., \& Patten, D. M. (2015). The normativity and legitimacy of CSR disclosure: Evidence from France. Journal of Business Ethics, 130(4), 789-803.

Ching, H. Y., Gerab, F., \& Toste, T. H. (2017). The quality of sustainability reports and corporate financial performance: Evidence from Brazilian listed companies. SAGE Open, 7(2), 2158244017712027.

Cho, C. H., Guidry, R. P., Hageman, A. M., \& Patten, D. M. (2012). Do actions speak louder than words? An empirical investigation of corporate environmental reputation. Accounting, organizations and society, 37(1), 14-25.

Cho, C. H., Laine, M., Roberts, R. W., \& Rodrigue, M. (2015). Organized hypocrisy, organizational façades, and sustainability reporting. Accounting, organizations and society, 40, 78-94.

Cho, C. H., Laine, M., Roberts, R. W., \& Rodrigue, M. (2018). The frontstage and backstage of corporate sustainability reporting: Evidence from the arctic national wildlife refuge bill. Journal of Business Ethics, 152(3), 865-886. https://doi.org/10.1007/s10551-016-3375-4

Çiğdem, F, Güneş, R, Çukacı, Y. (2018). The effects of internal control system on corporate governance: application in companies within the scope of best corporate governance index. journal of the institute of social sciences, 10 (25), 421-436. DOI: 10.20875/makusobed.423926

Clark, G. L., Feiner, A., \& Viehs, M. (2015). From the stockholder to the stakeholder: How sustainability can drive financial outperformance. Available at SSRN 2508281.

Correa-b, J. A., Garcia-Benau, M. A., \& Garcia-Meca, E. (2020). Corporate governance and its implications for sustainability reporting quality in Latin American business groups. Journal of Cleaner Production, 260, 121142 .

Daub, C. H. (2007). Assessing the quality of sustainability reporting: an alternative methodological approach. Journal of Cleaner Production, 15(1), 75-85.

Deegan, C. (2013). Financial accounting theory (4th ed.; N. S. North Ryde, Ed.). McGraw-Hill Education. 
The model for measuring the Quality of Sustainability Reporting...

63

Dichev, I. D., Graham, J. R., Harvey, C. R., \& Rajgopal, S. (2013). Earnings quality: Evidence from the field. Journal of Accounting and Economics, 56(2), 1-33.

Dissanayake, D., Tilt, C., \& Xydias-Lobo, M. (2016). Sustainability reporting by publicly listed companies in Sri Lanka. Journal of Cleaner Production, 129, 169-182.

Dominique Diouf, Olivier Boiral, (2017) "The quality of sustainability reports and impression management: A stakeholder perspective", Accounting, Auditing \& Accountability Journal, Vol. 30 Issue: 3, pp.643-667,

El-Rahman, A. (2019). Features Affecting the Quality of Sustainability Reporting: Theoretically-Informed Insights and Empirical Evidence from the Global Fortune 100 (2011-2015) (Doctoral dissertation, London South Bank University).

Farooque, O. A., \& Ahulu, H. (2017). Determinants of social and economic reportings: Evidence from Australia, the UK and South African multinational enterprises. International Journal of Accounting and Information Management, 25(2), 177-200.

Fatemi, A., Glaum, M., \& Kaiser, S. (2018). ESG performance and firm value: The moderating role of disclosure. Global Finance Journal, 38, 45-64.

Ferrell, A., Liang, H., \& Renneboog, L. (2016). Socially responsible firms. Journal of financial economics, 122(3), 585-606.

Ferri, L. M., Pedrini, M., \& Pilato, V. (2016). The management of stakeholder dialogue in different institutional contexts: An empirical study on FTSE4GOOD companies. Journal of Cleaner Production, 136, 226-236. https://doi.org/10.1016/j. jclepro.2016.01.100

Gao, F., Dong, Y., Ni, C., \& Fu, R. (2016). Determinants and economic consequences of non-financial disclosure quality. European Accounting Review, 25(2), 287-317.

Girón, A., Kazemikhasragh, A., Cicchiello, A. F., \& Panetti, E. (2020). Sustainability Reporting and Firms' Economic Performance: Evidence from Asia and Africa. Journal of the Knowledge Economy, 1-19

Gray, R. (2010). Is accounting for sustainability actually accounting for sustainability... and how would we know? An exploration of narratives of organisations and the planet. Accounting, organizations and society, 35(1), 47-62. 
Guenther, E., Hoppe, H., \& Poser, C. (2006). Environmental corporate social responsibility of firms in the mining and oil and gas industries: Current status quo of reporting following GRI guidelines. Greener Management International, 2006(53), 6-25. https://doi.org/0.9774/gleaf.3062.2006.sp.00003

Guthrie, J., \& Abeysekera, I. (2006). Content analysis of social, environmental reporting: What is new? Journal of Human Resource Costing \& Accounting, $10 \quad$ (2), 114-126. https://doi.org/10.1108/14013380610703120

Habibi, A., Izadyar, S., \& Sarafrazi, A. (2014). Fuzzy multi-criteria decision making. Rasht: Gilles Inscription Publication, 21-2.

Hamad, S., Draz, M. U., \& Lai, F. W. (2020). The Impact of Corporate Governance and Sustainability Reporting on Integrated Reporting: A Conceptual Framework. Sage Open, 10(2), 2158244020927431.

Hamidi, E., Nikkar, J., Hashemi Tilehnouei, M. (2021). The Impact of Corporate Social Responsibility on the Managers' Behaviors in Companies Listed on the Tehran Stock Exchange. Iranian Journal of Finance, 5(2), 128-151. doi: 10.30699/ijf.2021.256524.1168

Haque, F. (2017). The effects of board characteristics and sustainable compensation policy on carbon performance of UK firms. The British Accounting Review, 49(3), 347-364.

Harris, E. E. (2014). The impact of board diversity and expertise on nonprofit performance. Nonprofit Management and Leadership, 25(2), 113-130.

Helfaya, A., Whittington, M. and Alawattage, C. (2019), "Exploring the quality of corporate environmental

Reporting", Accounting, Auditing and Accountability Journal, Vol. 32 No. 1, pp. 163-193.

Hemmati, M., Fazeli, N., Saedodin, S. (2019). Social Value Added; A New Model for Developing Sustainability Accounting. Iranian Journal of Finance, 3(2), 105-128. doi: 10.22034/ijf.2020.206929.1082

Hill, J. (2020). Environmental, Social, and Governance (ESG) investing: A balanced analysis of the theory and practice of a sustainable portfolio. Academic Press. 
The model for measuring the Quality of Sustainability Reporting...

65

Hu, M., \& Loh, L. (2018). Board governance and sustainability disclosure: A cross-sectional study of Singapore-listed companies. Sustainability, 10(7), 2578.

Huang, R., \& Huang, Y. (2020). Does Internal Control Contribute to a Firm's Green Information Disclosure? Evidence from China. Sustainability, 12(8), 3197. MDPI AG. Retrieved from http://dx.doi.org/10.3390/su12083197

Iatridis, G. E. (2013). Environmental disclosure quality: Evidence on environmental performance, corporate governance, and value relevance. Emerging Markets Review, 14, 55-75.

Jadoon, I. A., Ali, A., Ayub, U., Tahir, M., \& Mumtaz, R. (2021). The impact of sustainability reporting quality on the value relevance of corporate sustainability performance. Sustainable Development, 29(1), 155-175.

Jensen, J. C., \& Berg, N. (2012). Determinants of traditional sustainability reporting versus integrated reporting. An institutionalist approach. Business Strategy and the Environment, 21(5), 299-316. https://doi.org/10.1002/bse.740

Jeong, H., \& Shin, K. (2020). Exploring Factors Affecting Sustainable Innovation Performance of Food Firms. A Case of Korean Food Industry. Sustainability, 12(23), 10157.

Kahraman, C. (Ed.). (2008). Fuzzy multi-criteria decision making: theory and applications with recent developments (Vol. 16). Springer Science \& Business Media.

Khan, H.Z., Bose, S., Mollik, A.T. and Harun, H. (2021), "Greenwashing" or "authentic effort"? An empirical investigation of the quality of sustainability reporting by banks", Accounting, Auditing \& Accountability Journal, Vol. 34 No. 2, pp. 338369. https://doi.org/10.1108/AAAJ-01-2018-3330

Khan, R., Khidmat, W. B., Hares, O. A., Muhammad, N., \& Saleem, K. (2020). Corporate governance quality, ownership structure, agency costs, and firm performance. Evidence from an emerging economy. Journal of Risk and Financial Management, 13(7), 154.

Krivačić, D. (2017). Sustainability reporting quality: the analysis of companies in Croatia. Journal of accounting and management, 7(1), 1-14. 
Lee, D. D., Faff, R. W., \& Langfield-Smith, K. (2009). Revisiting the vexing question: does superior corporate social performance lead to improved financial performance? Australian Journal of Management, 34(1), 21-49.

Li X (2020) The effectiveness of internal control and innovation performance: An intermediary effect based on corporate social responsibility. PLoS ONE 15(6): e0234506.

Li, X., Zheng, C., Liu, G., \& Sial, M. (2018). The Effectiveness of Internal Control and Corporate Social Responsibility: Evidence from Chinese Capital Market. Sustainability, 10(11), 4006. MDPI AG. Retrieved from http://dx.doi.org/10.3390/su10114006

Lončar, D., Paunković, J., Jovanović, V., \& Krstić, V. (2019). Environmental and social responsibility of companies across EU countries-Panel data analysis. Science of the total environment, 657, 287-296.

Lourenço, I. C., Branco, M. C., Curto, J. D., \& Eugénio, T. (2012). How does the market value corporate sustainability performance?. Journal of business ethics, 108(4), 417-428.

Luo, L., \& Tang, Q. (2014). Does voluntary carbon disclosure reflect underlying carbon performance?. Journal of Contemporary Accounting \& Economics, 10(3), 191-205.

Martínez, J. B., Fernández, M. L., \& Fernández, P. M. R. (2016). Corporate social responsibility: Evolution through institutional and stakeholder perspectives. European journal of management and business economics, 25(1), 8-14.

Mavlanova, T., Benbunan-Fich, R., \& Koufaris, M. (2012). Signaling theory and information asymmetry in online commerce. Information \& Management, 49(5), 240-247.

Michelon, G., Pilonato, S., \& Ricceri, F. (2015). CSR reporting practices and the quality of disclosure: An empirical analysis. Critical Perspectives on Accounting, 33, 59-78.

Milne, M. J., \& Gray, R. (2013). W(h)ither ecology? The triple bottom line, the global reporting initiative, and corporate sustainability reporting. Journal of Business Ethics, 118(1), 13-29. https://doi.org/10.1007/s10551-0121543-8

Morioka, S. N., Bolis, I., Evans, S., \& Carvalho, M. M. (2017). Transforming sustainability challenges into a competitive advantage: Multiple case 
The model for measuring the Quality of Sustainability Reporting... 67 studies kaleidoscope converging into sustainable business models. Journal of Cleaner Production, 167, 723-738.

Moses, E., Che-Ahmad, A., \& Abdulmalik, S. O. (2020). Board governance mechanisms and sustainability reporting quality: A theoretical framework. Cogent Business \& Management, 7(1), 1771075.

Munshi, D., \& Dutta, S. (2016). Sustainability reporting quality of Indian and American manufacturing firms: A comparative analysis. Serbian Journal of Management, 11(2), 245-260.

Needles, B. E., Frigo, M. L., Powers, M., \& Shigaev, A. (2016). Integrated reporting and sustainability reporting: An exploratory study of highperformance companies. Performance Measurement and Management Control: Contemporary Issues Studies in Managerial and Financial Accounting, $\quad 31, \quad 41-81 . \quad$ https://doi.org/10.1108/S1479351220160000031019

Nguyen, T. T. D. (2020). The Relationship Between Board of Directors and Sustainability Reporting: An Empirical Study In German Large Listed Firms. Acta Universitatis Agriculturae Et Silviculturae Mendelianae Brunensis, 68(1), 211-218.

Nilipour, Azadeh; De Silva, Tracy-Anne; and Li, Xuedong, The Readability of Sustainability Reporting in New Zealand over time, Australasian Accounting, Business and Finance Journal, 14(3), 2020, 86-107.

Nobanee, H., \& Ellili, N. (2016). Corporate sustainability disclosure in annual reports: Evidence from UAE banks: Islamic versus conventional. Renewable and Sustainable Energy Reviews, 55, 13361341.

Ong, S. H. (2016). Measuring the quality and identifying influencing factors of sustainability reporting: Evidence from the resources industry in Australia. Edith Cowan University. Retrieved from http://ro.ecu. edu.au/theses/1922

Orazalin, N., \& Mahmood, M. (2018). Economic, environmental, and social performance indicators of sustainability reporting: Evidence from the Russian oil and gas industry. Energy Policy, 121, 70-79.

Oshika, T., \& Saka, C. (2017). Sustainability KPIs for integrated reporting. Social Responsibility Journal, 13(3), 625-642. https://doi.org/10.1108/SRJ-07-2016-0122 
Rezaee, Z., \& Tuo, L. (2019). Are the quantity and quality of sustainability disclosures associated with the innate and discretionary earnings quality? Journal of Business Ethics, 155(3), 763-786.

Ruhana, A., \& Hidayah, N. (2020, February). The Effect of Liquidity, Firm Size, and Corporate Governance Toward Sustainability Report Disclosures (Survey on Indonesia Sustainability Report Award Participant). In 4th International Conference on Management, Economics and Business (ICMEB 2019) (pp. 279-284). Atlantis Press.

Ruiz-Lozano, M., \& Tirado-Valencia, P. (2016). Do industrial companies respond to the guiding principles of the Integrated Reporting framework? A preliminary study on the first companies joined the initiative. Revista de Contabilidad, 19(2), 252-260. https://doi.org/10.1016/j.rcsar.2016.02.001

Sehar, N., \& Tufail, S. (2013). Determinants of voluntary disclosure in the annual report: A case study of Pakistan. Management and Administrative Sciences Review, 2(2), 181-195. http://absronline.org/journals/index.php/masr/article/view/101

Seyed Khosroshahi, S., Vatankhah, P. (2017). The Relationship between Stock Market Liquidity, Firm Characteristics and Dividend Payout: Evidence from Tehran Stock Exchange. Iranian Journal of Finance, 1(1), 85-97. doi: 10.22034/ijf.2017.58461

Stefanescu, C. A., Oprisor, T., \& Sintejudeanu, M. A. (2016). An original assessment tool for transparency in the public sector based on the integrated reporting approach. Proceedings of the 11th International Conference Accounting and Management Information Systems (Amis 2016), 15(3), 503-520.

Taj, S. A. (2016). Application of signaling theory in management research: Addressing major gaps in the theory. European Management Journal, 34(4), 338-348.

Thurstone, L. L. (1927). A law of comparative judgment. Psychological Review, 34(4), 273.

Trumpp, C., Endrikat, J., Zopf, C., \& Guenther, E. (2015). Definition, conceptualization, and measurement of corporate environmental performance: A critical examination of a multidimensional construct. Journal of Business Ethics, 126(2), 185-204. 
The model for measuring the Quality of Sustainability Reporting...

69

Unerman, J., Bebbington, J., \& O'Dwyer, B. (2014). Sustainability accounting, and accountability. Routledge., 2014, 248-272. Retrieved from https://www.bokus.com/bok/9780415695589/sustainabilityaccountingand-accountability/

Velte, P., \& Stawinoga, M. (2017). Integrated reporting: The current state of empirical research, limitations, and future research implications. Journal of Management Control, 28(3), 275-320. https://doi.org/10.1007/s00187016-0235-4

Vitolla, F., Raimo, N., Rubino, M., \& Garzoni, A. (2020). The determinants of integrated reporting quality in financial institutions. Corporate Governance: International Journal of Business in Society, 20(3), 429444.

Wasara, T. M., \& Ganda, F. (2019). The relationship between corporate sustainability disclosure and firm financial performance in Johannesburg Stock Exchange (JSE) listed mining companies. Sustainability, 11(16), 4496.

Xie, J., Nozawa, W., Yagi, M., Fujii, H., \& Managi, S. (2019). Do environmental, social, and governance activities improve corporate financial performance? Business Strategy and the Environment, 28(2), 286-300.

\section{Bibliographic information of this paper for citing:}

Esmaeilzadeh, Habib; Ghodrati, Hasan; Jabbari, Hossein \& Arabzadeh, Meysam (2022). The model for measuring the Quality of Sustainability Reporting and Determinants: Application Analytic Network Process Fuzzy DEMATEL-Based Technique. Iranian Journal of Finance, 6(2), 28-69.

Copyright @ 2022, Habib Esmaeilzadeh, Hasan Ghodrati, Hossein Jabbari and Meysam Arabzadeh

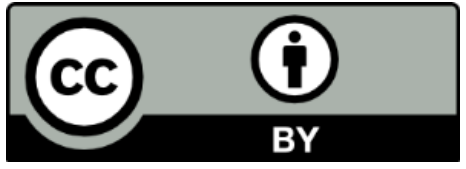

